\title{
第三紀層泥岩地すべり斜面の水文地質構造と地下水流動脈の関係
}

一新潟県板倉町の大池地すべりを例として一

\author{
今泉眞之 ${ }^{* 1} \cdot$ 奥山武彦 $* 2$ 備前信之*3
}

\section{The Relationship between Hydrogeologic Structure and Groundwater Vein-streams in the Tertiary Mudstone Landslide Slope, Niigata Prefecture}

\author{
Masayuki IMAIZUMI*1, Takehiko OKUYAMA*2 and Nobuyuki BIZEN*3
}

Key words : 地下水流動脈 groundwater vein-stream，第三紀層泥岩地すべり Tertiary mudstone landslide， 地温探査 underground temperature survey，放射能探査 radioactivity prospecting

\begin{abstract}
The Tertiary mudstone landslide slope around Ohoike pond in Itakura Town, Niigata Prefecture is complicated geologic structure characterized by the prevalence of faults and small landslides.

The strata of slope may be divided into fresh mudstone, weakly weathered mudstone, moderately weathered mudstone, strongly weathered mudstone and colluvial deposit from color and texture of boring core and $N$ values. The groundwater vein-streams run off throuth colluvial deposit, strongly weatherd mudstone and moderately weathered mudstone.

The underground temperature survey reveals three groundwater vein-streams; the West groundwater veinstream, the Center groundwater vein-stream and the East groundwater vein-stream. The gamma-ray spectrometry reveals the NNE direction fault system and NE direction faults system. The NNE direction fault system consist of the West fault, the Central fault and the East fault. The points of radon concentration anomalie of soil-gas coincide with back-scar, side-scar and cracks of foot part of small landslide configurations.

From the relationships of the distribution of groundwater vein-steams, fault and fissure zone of combination of the back-scar and side-scar of small landslides, it may be inferred as follows ;

(1) The West groundwater vein-stream runs off through the passage of crack caused by the West fault.

(2) The Center and the East groundwater vein-streams run off through the passages of fissure zones.
\end{abstract}

*1 国際農林水産業研究センター Japan International Research Center for Agricultural Sciences

*2 東北農業試験場 Tohoku National Agricultural Experiment Station

*3 北陸農政局 Hokuriku Regional Agricultural Administration Office

\section{1.は じめに}

第三紀層泥岩の地すべり斜面の地下水の流動形態は複 雑で，斜面土層状態に対応していくつかの層を成して存 在し, 地下水の賦存状態む層毎に異なることが知られて いる1)。また, 地すべり地内での透水試験やトレーサ調 
查からは, 地下水は透水係数 $10^{-4} \sim 10^{-6} \mathrm{~cm} / \mathrm{s}$ の崩積土 中の地下水流動脈（透水係数 $10^{1} \sim 10^{-1} \mathrm{~cm} / \mathrm{s}$ ) 中を流 下していることも知られている2)。

竹内 ${ }^{3)}$ は地下水流脈（水みち）を次のように記述して いる。「地すべり地内外の地下水は層状に均一に流動し ているのではなく, 土塊内の一部に透水性のより高い所 があり，そのような所が互いに連絡し合って水みちを形 成していると考えられる。つまり，地すべり地内外には 流動地下水と滞留地下水があり, 前者は水みちを流れ, 後者はいわゆる地下水層を形成している。2 種類の地下 水は分離して存在するのではなく, 滞留水（帯水層）の 中に流動水が包含されている形をとっていると推定され る。」「地下水流脈は地すべり地における地下水調查法の 一つである地下水流検層法, 温度検層法等によって周囲 の地下水と区分することが可能である。むた，平面的分 布状況は $1 \mathrm{~m}$ 深地温測定調查法によって知ることが可 能である ${ }^{4), 5)}$ 。これらの記述は, 地下水流動脈を水理 性から述べたもので, 地下水流動脈の成因については触 れていない。

地すべり地の地下水流動脈調查法には, 上記した調查 法以外に, トレーサ調査, 電気探査等がある。栃木・大 内6) は, 放射能探查と電気探査を併用して探查を行って いる。これらの調査結果に基づき地すべり防止工事が行 われ, 成果を上げているので, 地下水流動脈の存在自体 については確立されたものと考える。

新鮮な第三紀層泥岩は塊状で土粒子間の間隙も少ない ので地下水流動層とはなりえない。したがって, 第三紀 層泥岩地すべり斜面の地下水の流動を規制する要因は, 第三紀層の堆積後の構造運動や, 隆起後の斜面形成の過 程（地すべり・風化）で原岩の組織, 構造が変化して形 成された間隙, 亀裂等によっている。しかし, これまで の地下水流動脈の報告では, 野外の具体的な資料に基づ き地下水流動脈の成因にまで踏み込んだ議論はなされて いない。

新潟県板倉町の大池周辺の大規模な地すべり地では, これまでボーリング調査, 簡易揚水試験, 地下水検層等 の種々の調査が実施されているが, 個々の調査結果を結 びつけて, 地すべり斜面全体の地下水流動の実体を解明 することはできなかった。

著者らは, 大池地すべり斜面で $1 \mathrm{~m}$ 深地温探査, $\gamma$ 線 放射能探査, 土中ラドン $\left({ }^{222} \mathrm{Rn}\right)$ ガス調査を実施し, 地下水流動脈の分布, 断層・亀裂の分布を明らかにした うえで,これまで実施されていた調查結果を再検討し, 地下水流動脈々土層構造, 土層の水理特性, 地質構造々 の関係を検討した。その結果, 調査地域の地下水流動脈
の形成機構を明らかにすることができたので報告する。

調査に当たって農業工学研究所の小前隆美博士, 浜田 浩正氏には御協力をいたたいた。北陸農政局上越土地改 良建設事業所調査課の方々には種々の便宜を図っていた だいた。また，侏三祐コンサルタンツの大林市幸氏には 調查の一部を分担していたたいた。これらの方々に謝意 を表します。

\section{2. 調査地域の地形・地質}

調查地域は新潟県新井市の南東約 $5 \mathrm{~km}$ に位置する中 頝城郡板倉町の大池周辺である（図-1)。大池䧓辺は, 東頝城丘陵と呼ばれる標高 $500 \mathrm{~m}$ 内外の丘陵性山地で ある。

本地域に発達する新第三系・第四系は，中村7にによる 々, 層厚 $5,000 \mathrm{~m}$ 以上に及び，下位より上部中新統の富 倉層, 鮮新統の長沢 - 白岩層, 下部更新統の土路層・猿 橋層・小濁層に区分されている（表-1)。

各累層は, 大部分, 泥岩・砂岩・碩岩などの唯積岩か らなり, 富倉層の下部・長沢層の基底部・土路層の上部 層に，それぞれ安山岩溶岩・凝灰角磦岩が㣣在する。ま た，各累層に若干の酸性凝厕岩もはさまれる77。地すべ りは, 主として泥岩から成る富倉層（寺泊, 椎谷層に相 当する）の分布する地域に分布する。

調查地域の西方には, NNE 方向の軸を持ち, 軸面が 西に倒れた褶曲構造の富倉背斜がある7)。調查地域は, 富倉背斜と調和的な形態を示す複向斜構造の中にある。

表-1 地質層序

\begin{tabular}{|c|c|c|c|c|c|c|}
\hline 時 & 代 & \multicolumn{2}{|c|}{ 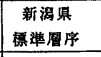 } & \multicolumn{2}{|c|}{$\begin{array}{l}\text { 中村 (1991) } \\
\text { 地简名: 箬厚 }\end{array}$} & 岩 \\
\hline 第 & 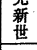 & \multicolumn{2}{|c|}{ 沖 㬝 } & & & 泥、础、砂砅 \\
\hline \multirow{3}{*}{ 四 } & 更 & \multicolumn{2}{|c|}{ 段丘堆䞍物 } & & & 泥、础、础硶 \\
\hline & \multirow[b]{2}{*}{ 世 } & \multirow{3}{*}{$\begin{array}{l}\text { 魚沼 } \\
\text { 港郡 }\end{array}$} & \multirow{2}{*}{ 上部 } & \multicolumn{2}{|c|}{ 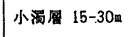 } & 础岩、シルト岩 磁岩 \\
\hline & & & & \multicolumn{2}{|c|}{ 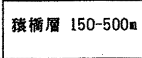 } & 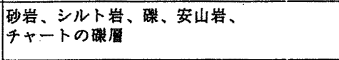 \\
\hline & & & \multirow{3}{*}{ 下部 } & \multirow{3}{*}{$\mid$\begin{tabular}{|l|} 
土路層 \\
220 -1500m
\end{tabular}} & 上部 & 安山岩䁈酸灭岩を挾有するシルト岩、砂岩 \\
\hline & \multirow{4}{*}{ 世 } & & & & 中部 & 铁灰岩、シルト岩、砂岩を挟有する璒岩 \\
\hline & & & & & 下部 & 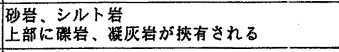 \\
\hline & & \multicolumn{2}{|c|}{ 灰爪展 } & \multicolumn{2}{|c|}{$\begin{array}{l}\text { 白岩層 } \\
120-380 \text { m }\end{array}$} & 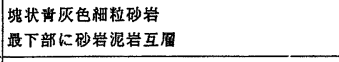 \\
\hline 第 & & \multicolumn{2}{|c|}{ 酞山厦 } & \multicolumn{2}{|c|}{$\begin{array}{l}\text { 長沢屬 } \\
\text { 60-520m }\end{array}$} & 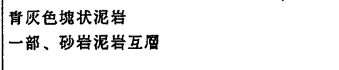 \\
\hline \multirow{2}{*}{ 能 } & 中 & \multicolumn{2}{|c|}{ 椎谷層 } & \multirow{2}{*}{\multicolumn{2}{|c|}{$\begin{array}{l}\text { 蔫會層 } \\
1800+\mathrm{m}\end{array}$}} & 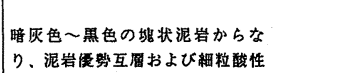 \\
\hline & $\begin{array}{l}\text { 新 } \\
\text { 世 }\end{array}$ & \multicolumn{2}{|c|}{ 寺泊痛 } & & & 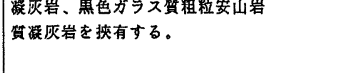 \\
\hline
\end{tabular}




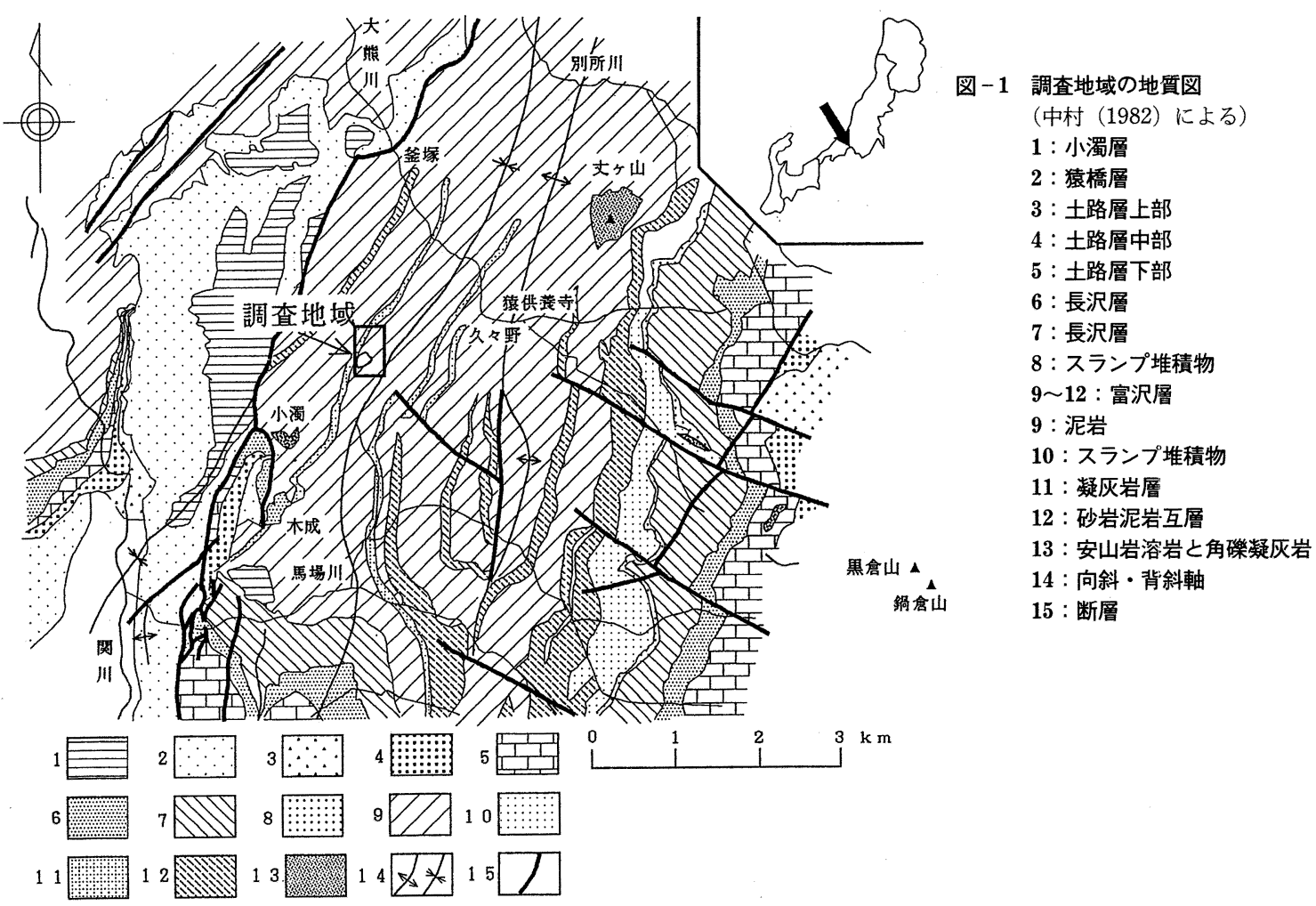

断層系は, 大局的には NNE 方向とWNW 方向の 2 方 向の構造要素から成り, 前者が支配的である7)。

調査地域は, NNE-SSW 方向に長軸を持ち, NNE 方向に緩やかに傾斜する比較的明瞭な地すべり地形を呈 している。ここでは，この地すべり地を大池地すべりと 呼ぶ。図-2には大池地すべり周辺の $100 \mathrm{~m} \times 100 \mathrm{~m}$ メ ッシュの接峰面図を示した。大池地すべりの周りには, 大池地すべりの西側で NW 方向へ傾動している「源治 ケ䆶地すべり」, 大池地すべり末端西側の $\mathrm{NE}$ 方向に延 び，NE 方向へ傾動する「大池周辺地すべり」が分布す る ${ }^{8)}$ 。大池地すべりと源治ケ窪地すべりとの境界は直線 的な尾根が存在し, 明瞭である。大池地すべりと大池周 辺地すべりの境界は不明膫である。

大池地すべりは，大池上流の分水嶺付近にある ENE 方向に延びる尾根を地すべり頭部としている。大池は, 標高 $425 \mathrm{~m}$ 付近に位置し，大池を中心として地すべり 地形冠頭部の標高 $500 \mathrm{~m}$ から, 標高 $400 \mathrm{~m}$ 付近までは 非常に緩傾斜の地形をなしている。標高 $400 \mathrm{~m}$ より低 標高部では，高標高部に比べれば傾斜が急となってい る。地すべり頭部付近には, 標高 $450 \mathrm{~m}$ 付近に残丘状 に基盤ブロック “離れ山”地形が分布する。大池の堤体
は離れ山の1つを利用し，一部を盛土して作られてい る。

接峰面図では, 分水嶺付近の尾根部以外に, 離れ山か らなる ENE 方向の尾根が見られ，平行する尾根に囲を れた陥没地形が見られる(図一-2)。陥没地形の前後に は馬蹄形状の滑落崖が発達している。この二重の滑落崖 の発達は，いわゆる破碎帯地すべり地で見られる稜線に 平行または若干斜交する線状凹地, 小崖地形9) と類似し たものと考えられる。

第三紀層地すべりは基盤岩型と浅層型とに分けられ る10)。基盤岩型地すべりは, (1)地震時などにより急激 に活動し，その後安定するもの，(2)長年月に継続的に滑 動するもの, (3)急激に活動した後, 緩慢な滑動に変わる ものなどがあるが，大池地すべりは(1)のタイプのもので ある。大池地すべり地内には，空中写真地形判読による 滑落崖, 緩斜面, 末端急傾斜地形の組反合わせと地表踏 查から図-3に示す小地すべり地が分布している。

調査地を構成する基盤岩は，富倉層の泥岩からなる。 調查地域の土地利用は主に水田(耕作放棄地も含まれる) で，一部に畑地，林地がある。基盤岩である泥岩は，調 查地の東西に位置するやせ尾根の裾部に露出している。 


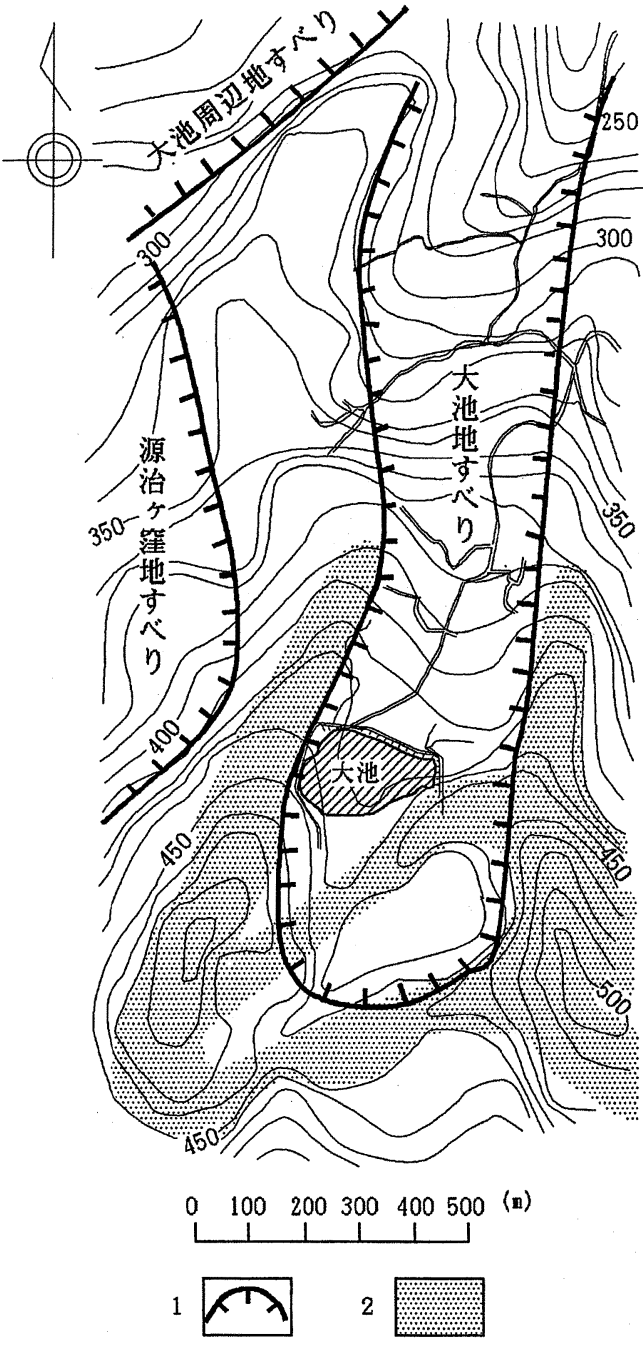

図-2 接峰図

$1:$ 地すべり地形 $2:$ 尾根部

基盤岩を覆う未固結層は基盤の風化物と崩積土である。

\section{3. 調 查 方 法}

\section{1 土層区分之簡易揚水試験}

大池地すべり内では図-4 に示す位置で土層構造と水 理特性を把握するためにボーリング，簡易揚水試験，地 下水検層等が実施されている9),11)。ボーリングコアでの 土層区分は, コアの色, 硬さ, 組織, 含水比, 割れ目の 状態の総合判断によって区分されるが，判断結果がボー リングコアの記載者によって異なるため, コアの形状 ・色と $N$ 值をもとに土層を再区分した。

簡易揚水試験はボーリング各孔において深度 $3 \mathrm{~m}$ 毎

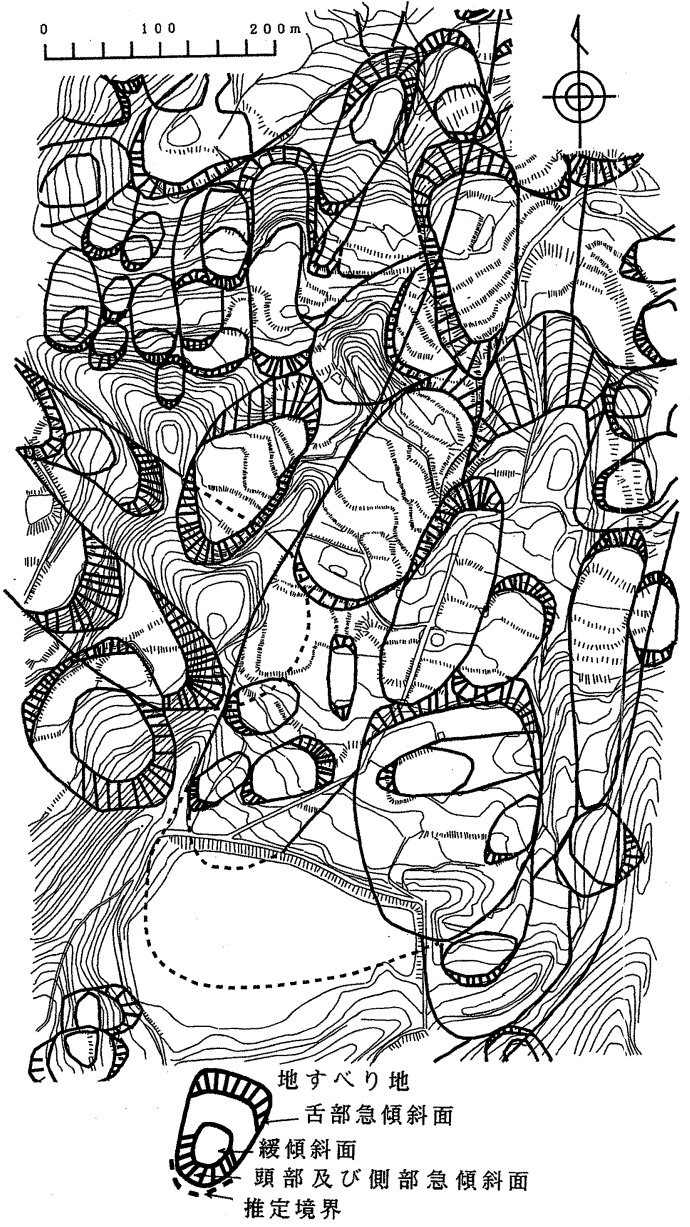

図-3 大池地すべり内の小地すべりブロックの分布図

に次の要領で行われ ${ }^{9)}$, 揚水の電気伝導度が測定されて いる。

(1)試験区間上端まで径 $86 \mathrm{~mm}$ で無水掘削し，ケーシ ングで遮水し, 試験区間は径 $66 \mathrm{~mm}$ で掘削する。

(2)各ボーリング孔の自然水位は $\mathrm{GL}-1 \mathrm{~m}$ 以下から $-5 \mathrm{~m}$ であった。各試験区間において，水位を試験区間 上端より $1 \mathrm{~m}$ 高く維持するように 40 分間揚水し，揚水 量を記録する。揚水後の回復水位は最初の 2 分間は, 30 秒間隔, 10 分間は 1 分間隔, 10 分以上は回復速度に より適宜測定する。

(3)透水係数はヤコブ式により計算する。孔内に水位が 存在しない場合，または揚水してからの水位回復がない 場合は, 注水法透水試験に変更し, 平均注水量より透水 係数を求める。 


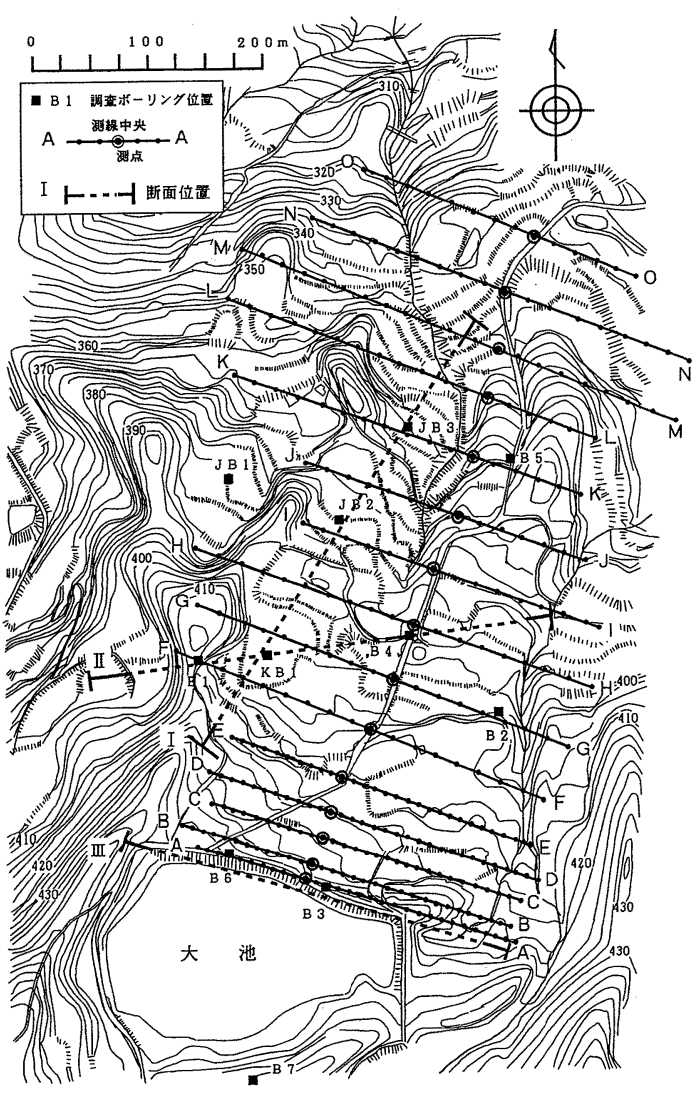

図-4 ボーリング, 測線, 断面位置図

\section{$3.21 \mathrm{~m}$ 深地温探査}

地下水流動脈の分布を明らかにするために，1 $1 \mathrm{~m}$ 深地 温探査を行った。測定原理, 測定方法の詳細は参考文 献3),12)を参照されたい。

地温は地下水流動脈以外に，植生状況や斜面の向きな ぞの影響を受けているが，これらの影響は局所的な地下 水流動脈の影響よりも大きな広がりを持っている。地下 水流動脈の位置の概定を, 地下水の流下方向と直交する 等高線方向に連続する測点群について, 次式で隣接 2 測点の平均地温に対する相対的差温（隣接測点平均差） を計算して，その異常值を抽出する方法で行った ${ }^{13)}$ 。

$$
\Delta \theta_{i, j}=\theta_{i, j}-\left(\theta_{i, j-1}+\theta_{i, j+1}\right) / 2
$$

$\theta_{i, j}:$ 測点 $i, j$ における $1 \mathrm{~m}$ 深地温

$i$ は傾斜方向, $j$ は等高線方向の配列を示す

測定は, 直径 $2 \mathrm{~cm}$, 深さ $1 \mathrm{~m}$ の孔をエンジンオーガ 一で穿孔し，孔底の地温を白金測温抵抗体温度センサー で測定した。温度測定器の分解能は $0.01^{\circ} \mathrm{Cである。}$

調查は1993年 9 月 20 日〜30日に行った。測定は, 大 池下流の斜面を横断する $\mathrm{A} \sim \mathrm{O}$ 測線で，測線間隔は $\mathrm{A}$
測線〜 $\sim$ 測線間は $12 \mathrm{~m}, \mathrm{~B}$ 測線〜 $\mathrm{E}$ 測線までの測線間隔 はおよそ $25 \mathrm{~m}, \mathrm{~F}$ 測線〜O 測線までの測線間隔はおよそ $50 \mathrm{~m}$ である（図 $-4:$ 測点は放射能探査の測点）。A〜 $\mathrm{C}$ 測線までは測定間隔 $4 \mathrm{~m}, \mathrm{D} \sim \mathrm{O}$ 測線は測是間隔 $20 \mathrm{~m}$ で行った。

\section{3 放射能探査}

大池地すべり地内の断層分布を調査するために，放射 能探査を行った。放射能探査は, 断層, 亀裂を上昇する ${ }^{222} \mathrm{Rn}$ ，断層粘土に吸着した ${ }^{238} \mathrm{U}$ を検出することにより 断層, 亀裂位置を探査する方法で, $\gamma$ 線スペクトロメト リーと土中 ${ }^{222} \mathrm{Rn}$ 濃度測定を行った。測定法の詳細は参 考文献14),15)を参照されたい。

$\gamma$ 線スペクトロメトリーに用いた装置は, クリアパル ス社製携帯用波高分析器，直径と高さが約 $13 \mathrm{~cm}$ の円筒 状の NaI 結晶と光電子倍増管を一体化したシンチレー ション検出器 1 セット等からなる。エネルギー分解能 は $7 \%$ 以下のものを使用した。測定核種は， ${ }^{40} \mathrm{~K}(1.46$ $\mathrm{MeV}),{ }^{214} \mathrm{Bi}(1.76 \mathrm{MeV}),{ }^{208 \mathrm{~T} 1}(2.62 \mathrm{MeV})$ である。1 回の測定時間は 5 分間である。測定值 $(N)$ の誤差 $(\sqrt{N})$ は，放出エネルギーが最小の ${ }^{214} \mathrm{Bi}$ でも $6 \%$ $[(\sqrt{N} / N) \times 100]$ 以下であった。

測定を短期間で行うために 3 台の測定器を使用した (測定器名 : 8355型, 1144-1 型, 1144-2 型)。8355 型と他の測定器の相関值をさむざまな地質条件で測定 し, 相関係数を求め, 各測定器間の補正を行った。 ${ }^{214} \mathrm{Bi},{ }^{208} \mathrm{Tl}$ の測定值の高エネルギー側のコンプトン散 乱線の補正は，ストリッピング法により除去した。 $\gamma$ 線 スペクトロメトリーは $1 \mathrm{~m}$ 深地温探査と同測線で行っ た。A〜E 測線までは測定間隔 $10 \mathrm{~m}, \mathrm{~F} \sim \mathrm{O}$ 測線は測定 間隔 $20 \mathrm{~m}$ で行った（図-4）。調査時には水田の刈り入 れ前だったので, 測定点が水田の中にある場合は, 適宜 前後左右に測定点をずらした。そのため, 測定結果で示 す放射能異常点の位置は, $10 \mathrm{~m}$ 程度の誤差を含んでい る。土中 ${ }^{22} \mathrm{Rn}$ ガス調查の測定は B 測線, G 測線, J 測 線で $10 \mathrm{~m}$ 間隔で行った。

\section{4. 調 査 結 果}

\section{1 土層区分}

一般に地すべり地内では, 表層から下位へ, 崩積土 層, 風化岩盤帯, 新鮮岩盤帯（基岩）の土層の層状構造 が知られている16)。崩積土層は, 基岩礫より成る場合 もあるが，基岩と全く異なる物質の場合もある。この層 は, 現在の風化生産物ではなく, 過去に移動して形成さ れた斜面物質で, 今後地すべりによって再移動する可能 性を持った土層でもある10)。 

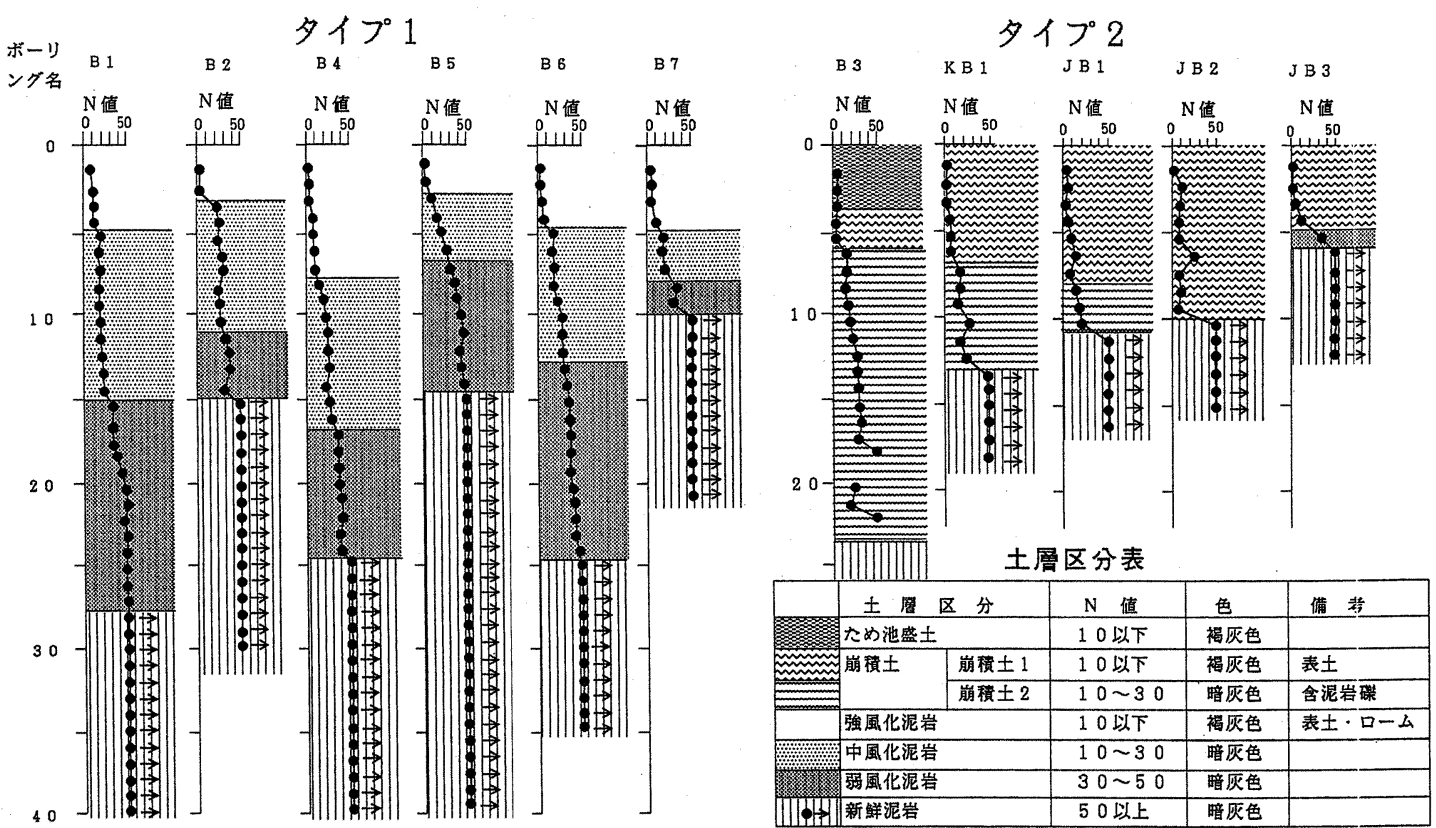

図-5 $N$ 値変化による土層区分

調査地域の11本のボーリングの $N$ 值の変化を調べる と, 大きく分けて図 -5 に示す 2 種類のタイプに区分で きる。タイプ 1 は表層の $N$ 值 10 以下から $N$ 值 50 以上ま でが漸移的に変化するタイプである。タイプ 2 は， $N$ 值50以下から $N$ 值50以上の間に $N$ 值 20 程度の不連続を 示すタイプである（図-5)。

タイプ 1 の柱状図では， $N$ 值50以上の暗灰色部を新 鮮泥岩, 50〜30の暗灰色部を弱風化泥岩, 30〜10の暗 灰色部を中風化泥岩, 10以下の灰色〜褐灰色を強風化 泥岩に区分した。強風化泥岩には，表土層も含まれる。 タイプ 2 の柱状図では, $N$ 值 50 以上を新鮮泥岩, $N$ 値 50 以下を崩積土層とした。崩積土層は上位の $N$ 値 10 以 下の軟弱な褐灰色のシルトから成る崩積土 1 と, 下位 の $N$ 值10～30の褐灰色～暗灰色の礫混じりシルトを崩 積土 2 とした。崩積土層 2 は, 䃯の混入の程度により $N$ 值が10３0まで不連続に変化する。崩積土層 2 とし たものの一部には, 弱風化泥岩が含まれている可能性が あるが，コアの形状・色と $N$ 值からでは区分できない ので, ここではタイプ 2 の新鮮泥岩以外は崩積土層と した。タイプ 1 は不動性の地盤が原位置で風化したも の, タイプ 2 の崩積土層は斜面崩壊により上部から移 動した崩積土が基岩上に再堆積したものと考えられる。

図-6に大池地すべりの縦断面図（地質断面 I ）を示 す。崩積土層は斜面に沿って分布している。新鮮岩も地 形と調和的に分布している。図-7 は大池地すべりの横
断面図（地質断面 II）である。ボーリング B1, B4 は夕 イプ 1 の $N$ 值変化を示し, $\mathrm{KB} 1$ はタイプ 2 の $N$ 值変 化を示す。 $N$ 值 50 以上の新鮮泥岩の上面深度は, KB1 が $\mathrm{B} 1, \mathrm{~B} 4$ より $10 \mathrm{~m}$ 程度浅くなっている。図 -6 の新鮮 泥岩の上面形から判断して, KB1 付近のみ新鮮岩の深 度が凸状に高くなることは考えにくいので，B1 と $\mathrm{KB} 1$ の間，KB1 と B4 の間には断層が推定される。図 -8 に大池堤体部の地質断面（III）を示す。測線 170 $\mathrm{m} \sim 210 \mathrm{~m}$ 付近は大池堤体の盛土である。B3 の堤体盛 土の下はタイプ $2, \mathrm{~B} 6$ はタイプ 1 の $N$ 値変化を示す。 B3 の崩積土の深度 $15 \mathrm{~m}$ 以深では， $N$ 值が20〜 50 まで 複雑に変化し，この部分には泥岩が㸴状に分布している ことが推定される。崩積土の分布範囲についてはボーリ ング資料が 2 本しかないので明らかでないが，堤体盛 土付近に谷状に分布しているものと考えた。この地下谷 地形は断層谷であると思われる。

\section{2 土層区分毎の水理特性}

94点の簡易揚水試験による透水係数（表 - 2) 上土層 区分の関係を検討するために，頻度分布図を作戌した (図 -9$)$ 。全体の平均透水係数は, $5.55 \times 10^{-5} \mathrm{crn} / \mathrm{s}$ で ある。

新鮮泥岩の平均透水係数は $2.08 \times 10^{-5}$ で山型の分布 を示すが，範囲は， $5.89 \times 10^{-4} \mathrm{~cm} / \mathrm{s} \sim 1.78 \times 10^{-7}$ $\mathrm{cm} / \mathrm{s}$ と広い。B5の深度 $15 \mathrm{~m} \sim 18 \mathrm{~m}$ の $5.89 \times 10^{-4}$ $\mathrm{cm} / \mathrm{s}$ は, 簡易揚水試験によって得られた透水係数で 2 


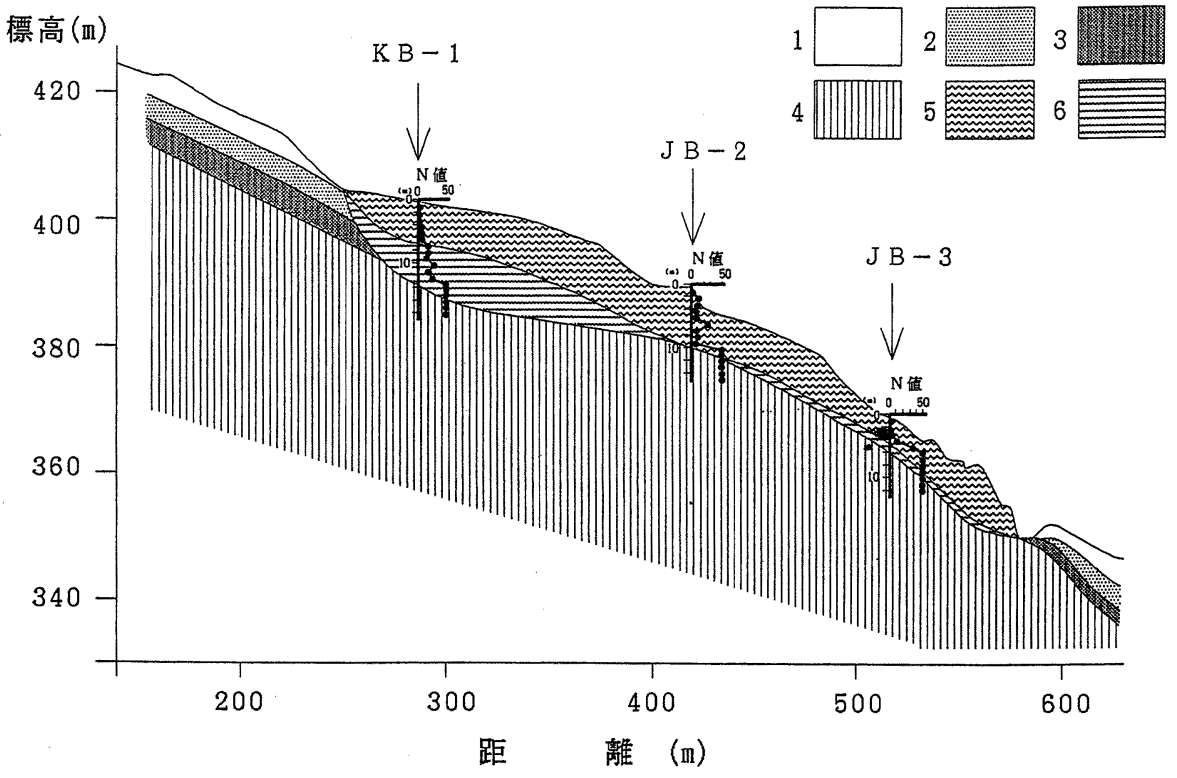

図-6 地質断面 I

$1:$ 強風化泥岩

$2:$ 中風化泥岩

$3:$ 弱風化泥岩

4: 新鮮泥岩

5: 崩皘土 1

6 : 崩積土 2

標高 $(\mathrm{m})$

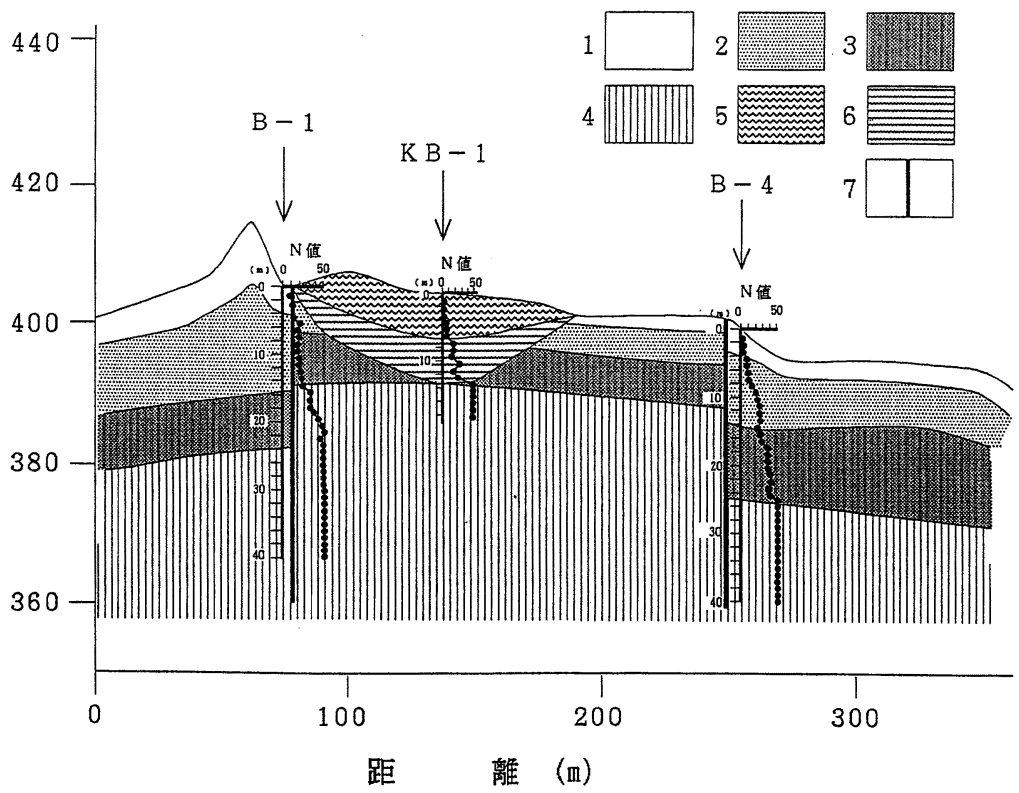

図 - 7 地兵断面 II

1 : 強風化泥岩

2 中風化泥岩

$3:$ 弱風化泥岩

4 : 新鮮泥岩

5 : 崩積土 1

$6:$ 崩皘土 2

7 : 断層

距

離 （m）

番目に大きな值である。弱風化泥岩も新鮮泥岩と同じよ うな分布を示すが, 平均透水係数は $1.87 \times 10^{-5} \mathrm{~cm} / \mathrm{s}$ で やや大きい。中風化泥岩は図-9 に示すような 2 つ山 を持つ分布を示し，主要な山は $5 \times 10^{-5} \mathrm{~cm} / \mathrm{s}$ にあり， もう一つの山は $5 \times 10^{-4} \mathrm{~cm} / \mathrm{s}$ にある。強風化泥岩は平 均透水係数が最も大きく $2.77 \times 10^{-4} \mathrm{~cm} / \mathrm{s}$ であり, 山型 の分布を示す。新鮮泥岩から強風化泥岩へ風化ととも に, 平均透水係数, 頻度分布の山の透水係数が増加して
いる。崩積土層の平均透水係数は $9.21 \times 10^{-5} \mathrm{~cm} / \mathrm{s}$ であ るが，新鮮岩と同じように $6.14 \times 10^{-4} \mathrm{~cm} / \mathrm{s} \sim 3.00 \times$ $10^{-7} \mathrm{~cm} / \mathrm{s}$ の広い範囲を示し，その分布は中風化泥岩と 同じように $2 つ$ つ型を示す。主要な山は $5 \times 10^{-5}$ $\mathrm{cm} / \mathrm{s}$ にあり，もう一つの山は $5 \times 10^{-4} \mathrm{~cm} / \mathrm{s}$ にある。 B3の $3 \mathrm{~m} \sim 6 \mathrm{~m}$ の $6.14 \times 10^{-4} \mathrm{~cm} / \mathrm{s}$ は最も大きな透水 係数で, 推定した断層谷の存在を裏付ける。

タイプ 1 の深度方向の透水係数分布は, 一般的には 


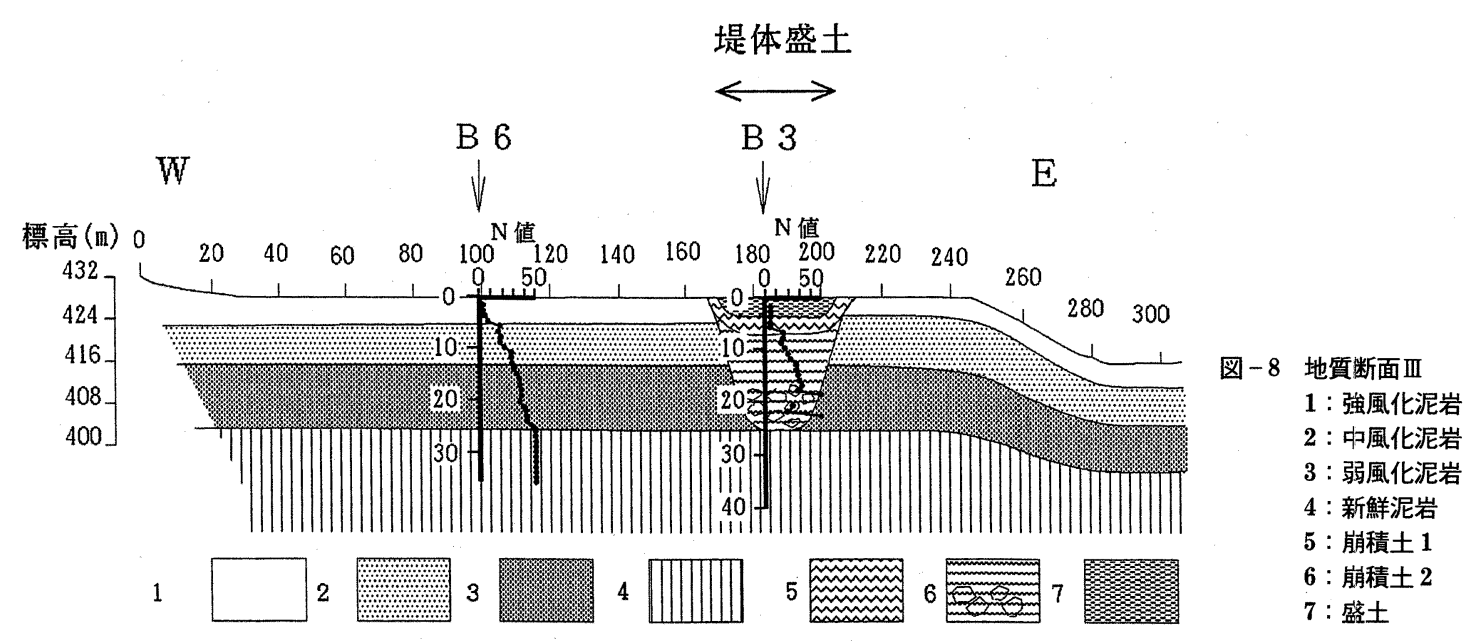

表 -2 簡易揚水試験結果

\begin{tabular}{|c|c|c|c|c|c|c|c|c|c|c|c|c|c|c|}
\hline \multirow[b]{2}{*}{ 深度 $(\mathrm{m})$} & \multicolumn{2}{|l|}{ B 1} & \multicolumn{2}{|l|}{ B 2} & \multicolumn{2}{|l|}{ B 3} & \multicolumn{2}{|l|}{ B 4} & \multicolumn{2}{|l|}{ B 5} & \multicolumn{2}{|l|}{ B 6} & \multicolumn{2}{|l|}{ B 7} \\
\hline & $\begin{array}{l}\text { 透水係数 } \\
(\mathrm{cm} / \mathrm{sec})\end{array}$ & $\mathrm{EC}$ & $\begin{array}{l}\text { 透水係数 } \\
(\mathrm{cm} / \mathrm{sec})\end{array}$ & $\mathrm{EC}$ & $\begin{array}{l}\text { 透水係数 } \\
(\mathrm{cm} / \mathrm{sec})\end{array}$ & $\mathrm{EC}$ & $\begin{array}{l}\text { 透水係数 } \\
(\mathrm{cm} / \mathrm{sec})\end{array}$ & $\mathrm{EC}$ & $\begin{array}{l}\text { 透水係数 } \\
(\mathrm{cm} / \mathrm{sec})\end{array}$ & $\mathrm{EC}$ & $\begin{array}{l}\text { 透水係数 } \\
(\mathrm{cm} / \mathrm{sec})\end{array}$ & EC & $\begin{array}{l}\text { 透水係数 } \\
(\mathrm{cm} / \mathrm{sec})\end{array}$ & $\mathrm{EC}$ \\
\hline $\begin{array}{l}3 \sim 6 \\
6 \sim 9 \\
9 \sim 12 \\
2 \sim 15 \\
5 \sim 18 \\
8 \sim 21 \\
1 \sim 24 \\
4 \sim 27 \\
7 \sim 30 \\
30 \sim 33 \\
33 \sim 36 \\
36 \sim 39\end{array}$ & $\begin{array}{l}3.43 \times 10^{-5} \\
2.74 \times 10^{-6} \\
3.88 \times 10^{-6} \\
5.92 \times 10^{-8} \\
6.31 \times 10^{-8} \\
1.00 \times 10^{-5} \\
6.38 \times 10^{-8} \\
8.16 \times 10^{-7} \\
4.76 \times 10^{-8} \\
2.48 \times 10^{-8} \\
1.11 \times 10^{-8} \\
6.46 \times 10^{-8}\end{array}$ & 911 & $\begin{array}{l}2.56 \times 10^{-4} \\
3.98 \times 10^{-5} \\
1.50 \times 10^{-5} \\
1.32 \times 10^{-5} \\
7.13 \times 10^{-5} \\
3.53 \times 10^{-8} \\
2.87 \times 10^{-8} \\
3.03 \times 10^{-8} \\
3.19 \times 10^{-8}\end{array}$ & $\begin{array}{r}110 \\
180 \\
470 \\
545 \\
861 \\
783 \\
1355 \\
924 \\
936\end{array}$ & $\begin{array}{l}6.14 \times 10^{-4} \\
3.17 \times 10^{-5} \\
2.99 \times 10^{-5} \\
2.18 \times 10^{-5} \\
8.89 \times 10^{-8} \\
1.41 \times 10^{-8} \\
6.97 \times 10^{-8} \\
2.04 \times 10^{-7} \\
1.78 \times 10^{-7} \\
5.36 \times 10^{-8} \\
3.67 \times 10^{-7} \\
7.25 \times 10^{-7}\end{array}$ & $\begin{array}{r}64.9 \\
111 \\
174.6 \\
310 \\
325 \\
239 \\
295 \\
342 \\
322 \\
370 \\
340 \\
294\end{array}$ & $\begin{array}{l}3.99 \times 10^{-4} \\
8.77 \times 10^{-5} \\
3.49 \times 10^{-5} \\
3.26 \times 10^{-5} \\
6.54 \times 10^{-8} \\
9.38 \times 10^{-8} \\
9.97 \times 10^{-8} \\
6.41 \times 10^{-8} \\
7.21 \times 10^{-8} \\
5.09 \times 10^{-8} \\
4.99 \times 10^{-8} \\
4.09 \times 10^{-8}\end{array}$ & $\begin{array}{r}200 \\
680 \\
720 \\
315 \\
213 \\
245 \\
253 \\
1586 \\
672 \\
1791 \\
710 \\
373\end{array}$ & $\begin{array}{l}1.12 \times 10^{-4} \\
2.61 \times 10^{-5} \\
1.88 \times 10^{-8} \\
1.97 \times 10^{-8} \\
5.89 \times 10^{-4} \\
1.38 \times 10^{-8} \\
1.59 \times 10^{-8} \\
9.57 \times 10^{-7} \\
4.59 \times 10^{-7} \\
1.38 \times 10^{-8} \\
1.50 \times 10^{-8} \\
1.14 \times 10^{-8}\end{array}$ & $\begin{array}{l}234 \\
222 \\
295 \\
201 \\
739 \\
722 \\
851 \\
783 \\
776 \\
239 \\
231 \\
772\end{array}$ & $\begin{array}{l}2.23 \times 10^{-4} \\
7.97 \times 10^{-5} \\
1.09 \times 10^{-5} \\
6.89 \times 10^{-8} \\
9.11 \times 10^{-8} \\
1.07 \times 10^{-6} \\
1.73 \times 10^{-5} \\
3.81 \times 10^{-8} \\
2.76 \times 10^{-8} \\
3.03 \times 10^{-8} \\
4.74 \times 10^{-8}\end{array}$ & $\begin{array}{r}325 \\
673 \\
477 \\
1396 \\
1648 \\
1844 \\
432 \\
532 \\
1324\end{array}$ & $\begin{array}{l}3.99 \times 10^{-4} \\
2.99 \times 10^{-4} \\
1.50 \times 10^{-4} \\
1.81 \times 10^{-5} \\
2.27 \times 10^{-5} \\
1.17 \times 10^{-5}\end{array}$ & $\begin{array}{r}140 \\
70 \\
910 \\
930 \\
938 \\
273\end{array}$ \\
\hline \multirow[b]{2}{*}{ 深度 $(\mathrm{m})$} & \multicolumn{2}{|l|}{ K B 1} & \multicolumn{2}{|l|}{ J B 1} & \multicolumn{2}{|c|}{ J B 2} & \multicolumn{2}{|l|}{ J B 3} & \multirow{2}{*}{\multicolumn{6}{|c|}{$\mathrm{EC}$ ：電気伝首度 $(\mu \mathrm{S} / \mathrm{cm})$}} \\
\hline & $\begin{array}{l}\text { 透水係数 } \\
(\mathrm{cm} / \mathrm{sec})\end{array}$ & EC & $\begin{array}{l}\text { 透水係数 } \\
(\mathrm{cm} / \mathrm{sec})\end{array}$ & $\mathrm{EC}$ & $\begin{array}{l}\text { 透水係数 } \\
(\mathrm{cm} / \mathrm{sec})\end{array}$ & $\mathrm{EC}$ & $\begin{array}{l}\text { 透水係数 } \\
(\mathrm{cm} / \mathrm{sec})\end{array}$ & $\mathrm{EC}$ & & & & & & \\
\hline $\begin{aligned} 0 & \sim 3 \\
3 & \sim 6 \\
6 & \sim 9 \\
9 & \sim 12 \\
12 & \sim 15 \\
15 & \sim 18\end{aligned}$ & $\begin{array}{l}2.90 \times 10^{-5} \\
\text { 5. } 00 \times 10^{-5} \\
\text { 3. } 60 \times 10^{-8} \\
\text { 3. } 00 \times 10^{-7} \\
4.60 \times 10^{-7} \\
\text { 2. } 40 \times 10^{-7}\end{array}$ & $\begin{array}{l}119 \\
497 \\
731 \\
604 \\
167 \\
463\end{array}$ & $\begin{array}{l}4.30 \times 10^{-4} \\
5.60 \times 10^{-5} \\
2.70 \times 10^{-5} \\
\text { 3. } 40 \times 10^{-5} \\
1.00 \times 10^{-5}\end{array}$ & $\begin{array}{r}339 \\
404 \\
777 \\
1850 \\
1114\end{array}$ & $\begin{array}{l}9.24 \times 10^{-8} \\
2.70 \times 10^{-8} \\
1.84 \times 10^{-4} \\
2.40 \times 10^{-4} \\
3.60 \times 10^{-6}\end{array}$ & $\begin{array}{r}91 \\
1440 \\
615\end{array}$ & $\begin{array}{l}2.00 \times 10^{-4} \\
7.30 \times 10^{-8} \\
1.40 \times 10^{-5} \\
9.60 \times 10^{-7}\end{array}$ & $\begin{array}{r}73 \\
351 \\
765 \\
645\end{array}$ & & & & & & \\
\hline
\end{tabular}

強風化泥岩, 中風化泥岩の表層部で透水係数が高く, 弱 風化泥岩, 新鮮泥岩で低くなる。しかし, 新鮮泥岩に亀 裂がある場合（B5）は，亀裂部でその上下層に比較し て 2 オーダの違いがある。タイプ 2 の崩積土層中での 深度方向の透水係数分布は, KB1, JB1 の表層部で高 く, 崩積土下部で低くなるタイプと, JB2 の崩積土層下 部で高くなるタイプがある。JB2 の高透水性部はすべり 面の直下で地すべり運動により生じた亀裂による透水性 帯であると考えられる18)。

\section{3 土層区分毎の水質の電気伝導度 $(\mathrm{EC})$}

図-10には, 揚水試験毎に採水した孔内水の $\mathrm{EC}$ の頻 度分布図を示した。 $\mathrm{EC}$ の平均は595.5 $\mu \mathrm{S} / \mathrm{cm}$ で65 $\mu \mathrm{S} / \mathrm{cm} \sim 1850 \mu \mathrm{S} / \mathrm{cm}$ の範囲を示す。崩積土層の $\mathrm{EC}$ の
範囲は全体の範囲と同じであるが, 平均値は 478 $\mu \mathrm{S} / \mathrm{cm}$ で全体よりやや低い。崩積土層中の高 EC（700 $\mu \mathrm{S} / \mathrm{cm}$ 以上）は地すべり面のモンモりロナイトの形成 と関係した地下水水質である (今泉, 準備中)。強風化 泥岩 (平均 : $340 \mu \mathrm{S} / \mathrm{cm}$ ), 中風化泥岩（平均293 $\mu \mathrm{S} / \mathrm{cm})$ のEC は $720 \mu \mathrm{S} / \mathrm{cm}$ 以下を示す。一方, 弱風化 泥岩, 新鮮泥岩の $\mathrm{EC}$ は平均値はそれぞれ $624 \mu \mathrm{S} / \mathrm{cm}$, $749 \mu \mathrm{S} / \mathrm{cm}$ でり, 範囲は $201 \mu \mathrm{S} / \mathrm{cm} \sim 1648 \mu \mathrm{S} / \mathrm{cm}$, $167 \mu \mathrm{S} / \mathrm{cm} \sim 1844 \mu \mathrm{S} / \mathrm{cm}$ の広い範囲を示している。

タイプ1の $\mathrm{EC}$ の垂直分布は, 表層部で低く, 弱風化 泥岩, 新鮮泥岩で高くなっている。タイプ 2 の表層部 で高透水係数を示す部分の地下水は低 EC を示し, 崩積

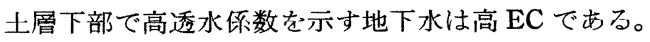




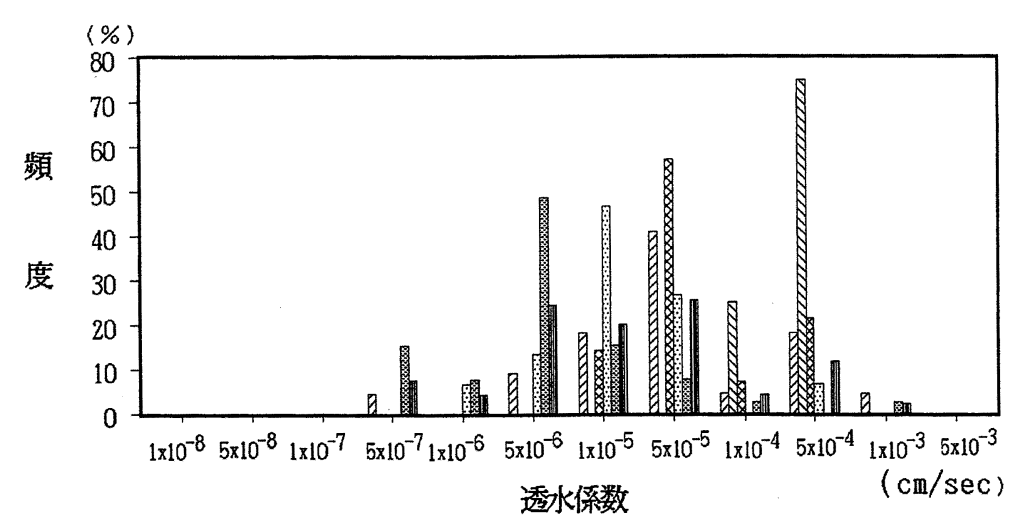

強風化泥岩凶中風化泥岩 圈 弱風化泥岩 图 新鲜尼岩曰崩積土㬝 四 全体

図 -9 土層区分毎の透水係数の頻度分布図

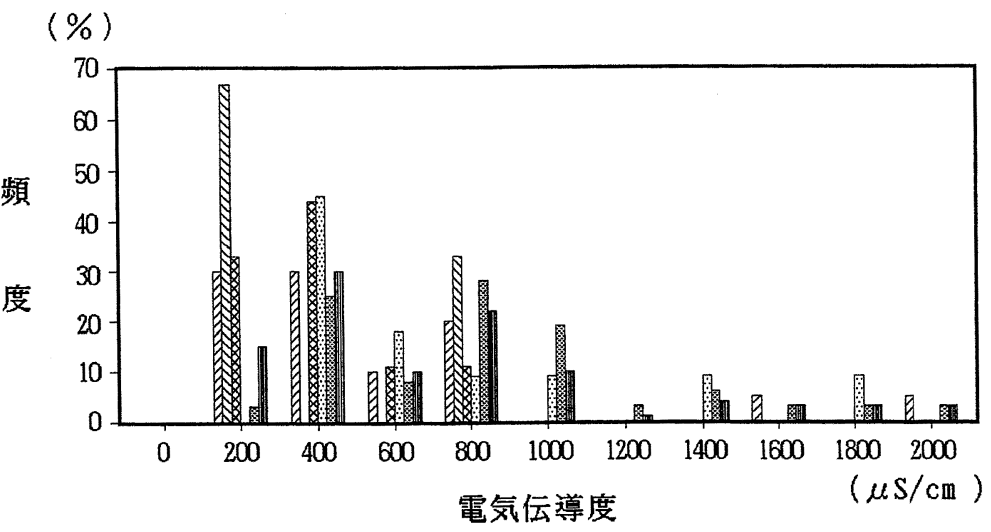

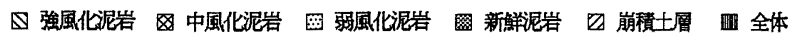
図-10 土層区分毎の電気伝導度の頻度分布図

\section{$4.41 \mathrm{~m}$ 深地温探査による地下水流動脈分布}

調查を行った 9 月下旬は 1 年のうちでも地温が高い 季節に当たり, 地下水温と地温との温度差は $5 \sim 6{ }^{\circ} \mathrm{C}$ あ った。隣接測点平均差法によって, 両隣測点の平均地温 より $0.5^{\circ} \mathrm{C}$ 以上低温である測点を抽出することによって 推定された地下水流動脈の平面分布図を図一11に示す。 大きく分けて, 大池左岸から流出する地下水流動脈（以 下, 西地下水流動脈と言う), 大池是体中央部加流出 する地下水流動脈（以下, 中央地下水流動脈と言う）, 大池の東側の沢沿いを流下する地下水流動脈（以下，東 地下水流動脈と言う）の 3 本の地下水流動脈が見られ る。

\section{5 放射能探查による断層, 亀裂の推定}

(1) $\gamma$ 線スペクトロメトリー

コンプトン散乱線を補正した ${ }^{214} \mathrm{Bi}$ は最大值 715 , 最小 值162, 平均 405.8, 標準偏差90.6, ${ }^{208} \mathrm{Tl}$ は最大値986, 最小值 248 , 平均 600.0 , 標準偏差113.4であった。
今泉他 ${ }^{14)}$ は断層の指標として ${ }^{214} \mathrm{Bi} /{ }^{208} \mathrm{Tl}$ が有効である ことを報告している。図 -12 に $\mathrm{A} \sim \mathrm{E}$ 測線の ${ }^{214} \mathrm{Bi} /{ }^{208} \mathrm{Tl}$ 值の変化を示す。図中の矢印は, 各測線毎に ${ }^{214} \mathrm{Bi} / 208 \mathrm{Tl}$ の 5 回の測定の移動平均值を求め, この平均值を分母 とし, 各測定値の ${ }^{214} \mathrm{Bi} /{ }^{208} \mathrm{Tl}$ 值を分子とした增減の相対 百分率で ${ }^{16)}$, 增加百分率が $5 \%$ 以上の異常点である。 図-13に異常点の平面分布を示す。

\section{(2) 土中 ${ }^{222} \mathrm{Rn}$ 濃度調查}

表 -3 に $\mathrm{B}, \mathrm{G}, \mathrm{J}$ 測線の ${ }^{22} \mathrm{Rn}$ 濃度を示す。最小值は $3.4 \mathrm{pCi} / l$, 最大值は $300.0 \mathrm{pCi} / l$, 平均值は $47.4 \mathrm{pCi} / l$, 標準偏差46.1であった。図-14に 3 測線の ${ }^{222} \mathrm{Rn}$ 濃度変 化を示す。図中に矢印で示した点は, 測線毎の平均値に 刘ずる測定値の增加率が50\%以上の異常点である。B 測線では東 $170 \mathrm{~m}$ 地点は $507 \%$ 増の異常を示す。この他 $\mathrm{B}$ 測線には東 $60 \mathrm{~m}$ 付近 $(60 \sim 96 \%)$ ，西50 $\mathrm{m}(224 \%)$ に異常点がある。G 測線では東80 m (193\%)， $40 \mathrm{~m}$ (50\%), 西10 m (83\%), $120 \mathrm{~m}(101 \sim 193 \%)$ 付近に異 


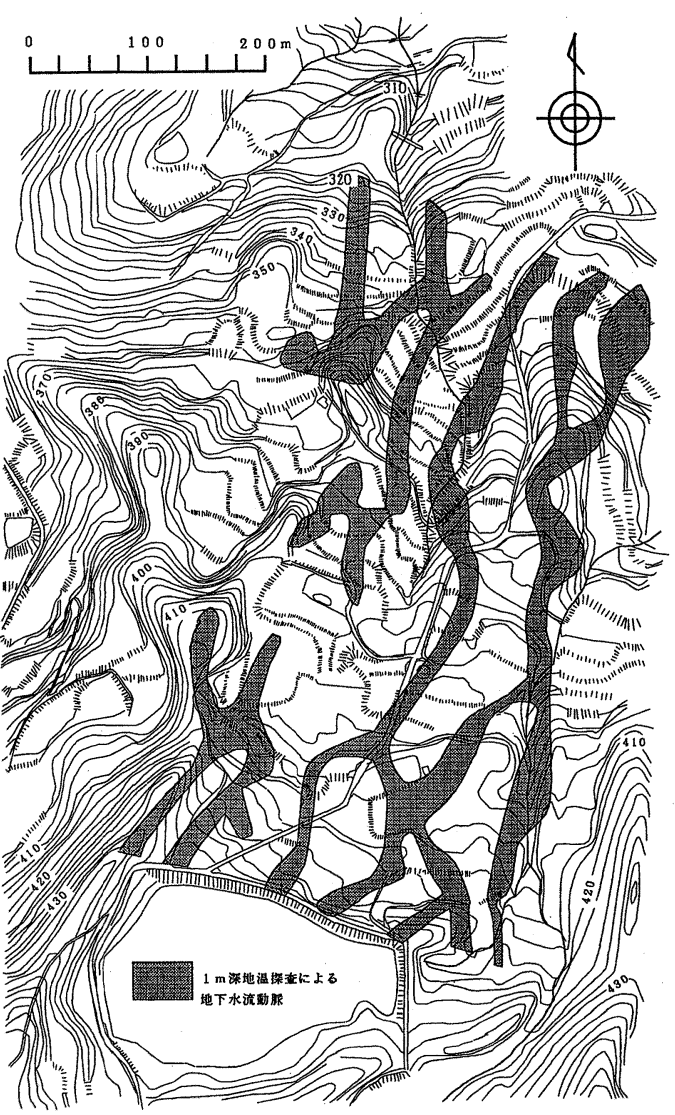

図-11 $1 \mathrm{~m}$ 深地温探査による地下水脈分布図

常点がある。J 測線には中央付近 $(53 \sim 190 \%)$ ，西30 $\mathrm{m}(295 \%), 120 \mathrm{~m}(243 \%)$ に異常点がある。

\section{5. 考察}

\section{1 地すべりの変形構造と放射能異常点の関係}

地すべりの変形構造は，地すべりが運動することによ って形成される16)(図-15)。地すべり土塊は地すべり 面上を滑動する。1つの地すべりでは，滑動した土塊の 上部は頭部で陥没し，中部はそのまま動き，下部は押し 出して隆起した地形を示す。

地すべり性の亀裂には，地すべり土塊上部の滑落崖 -二次滑落崖, 側方の滑落崖, 末端隆起部の亀裂等多 くの形態があり，これらはしばしば互いに連鎖したり， 漸移したりしながら，全体としては地下水流動脈網を形 成していると考えられる。また，亀裂は直接地下水の水 みちとしての役割のほか, 地表面では地表水を地下に導 き, 地下水を湧出させる等の働きもある17)。

地すべり底部にはすべり面という独特の土層が生じ， これを境に原地盤の上を土塊が滑動する。すべり面の直
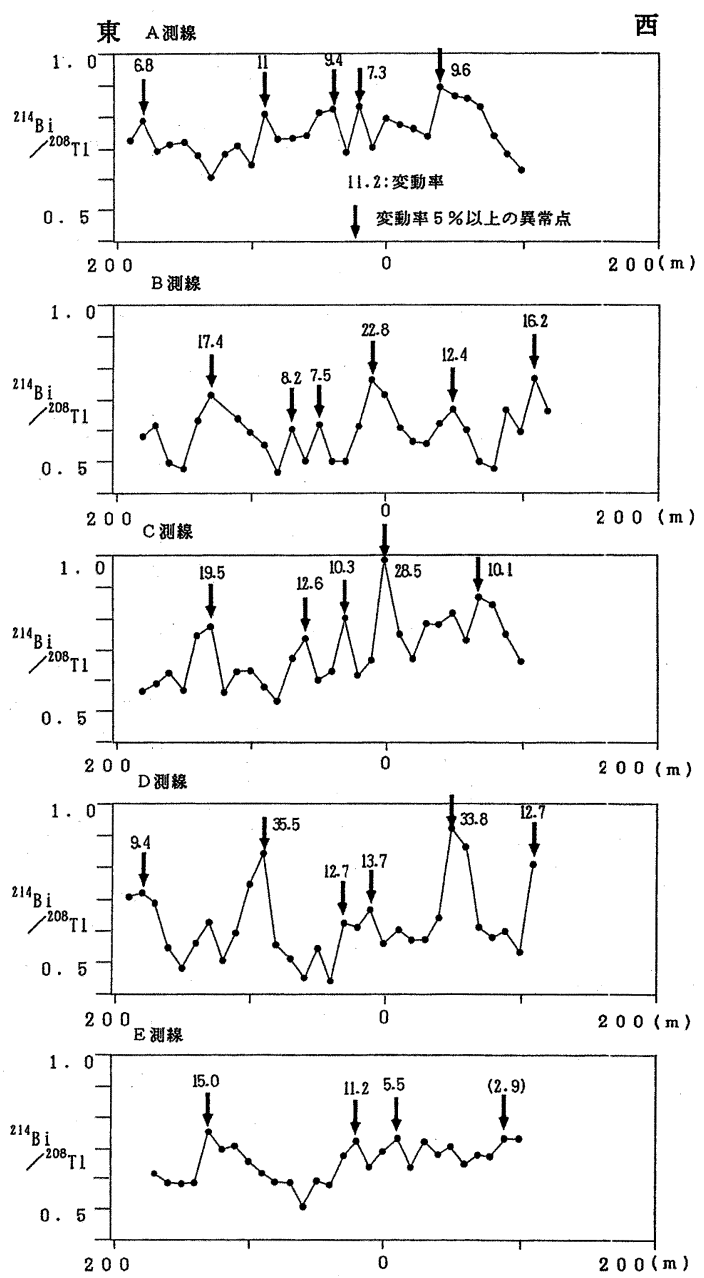

図-12 $\quad \mathrm{A} \sim \mathrm{E}$ 測線の ${ }^{214} \mathrm{Bi} /{ }^{208} \mathrm{Tl}$ の変化と異常点

下には破砕による亀裂が生じ, 一種の透水帯が存在す $ろ^{18)}$ 。

実際の地すべり斜面では, 比較的急激に移動する軟弱 な表層部地すべりとこれらを包括する中規模程度の地す ベり，さらに基盤上面をすべり面とする大規模地すべり 等のように，いくつかの規模の地すべりが重合したもの になっている19)。さらに，地すべり斜面には断層，節 理等の亀裂もあり, 複雑な構造になっている。

図一 13 には ${ }^{214} \mathrm{Bi} /{ }^{208} \mathrm{~T} 1$ の異常点のほかに ${ }^{222} \mathrm{Rn}$ 濃度の 異常点分布も示されている。B 測線では両者はほぼ同じ 位置にあるが， G 測線, J 測線では一致しない場合が多 い。これは， ${ }^{22} 2 \mathrm{Rn}$ 濃度変化が土鉙間隙中の ${ }^{222} \mathrm{Rn}$ 濃度 を測定しているのに対し, ${ }^{214} \mathrm{Bi}$ は主に土壤・基盤中の ${ }^{238} \mathrm{U}(\mathrm{U})$ 含有量と関係していることにある ${ }^{15)} 。$

海成の黒色頁岩に含まれる堆積性ウラン鉱床の研究に 


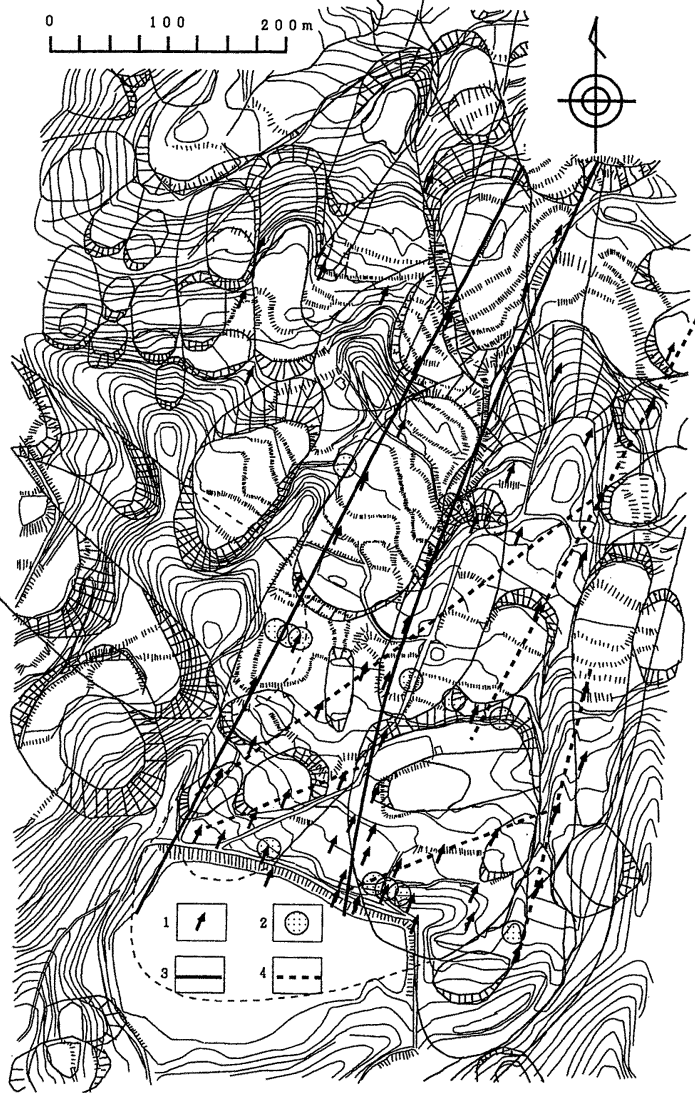

図 - $13 \quad{ }^{214} \mathrm{Bi} /{ }^{208} \mathrm{Tl}$ の異常点分布図

$1:{ }^{214} \mathrm{Bi} /{ }^{208} \mathrm{Tl}$ の異常点

$2:$ 土中 ${ }^{222} \mathbf{R n}$ 濃度の異常点

$3:$ 確実度の高い断層 $4:$ 確実度の劣る断層

よると，Uは独自の鉱物としては産せず，岩石全体に わたってほほ一様に分散している。Uは有機物, 粘土 鉱物に吸着されていると考えられている20)。調査地域 の泥岩中のU 含有量についての資料がないが，黒色頁 岩中のウラン鉱床でのU の分布から推定して, 堆積時 のU 含有量は均一であったものと考えられる。

火成岩では U とトリウム（Th）の濃度には相関性が あるが, 堆積, 風化過程では, U と Th は化学的挙動が 異なっている。火成岩の鉱物中では両元素ともに $4^{+}$の 酸化状態で存在しているが，U は地表面環境下では $5^{+}$, $6^{+}$の原子価状態に酸化される。 $6^{+}$酸化状態は最も安定 であり, 可溶性のウラニル $\left(\mathrm{UO}_{2}{ }^{2+}\right)$ 錯イオンを生成す $ろ^{21)}$ 。U は地下水中で錯イオンとして移動するか，あ るいはデトリタルな沈殿物として移動する。Th は地表 面環境下でも酸化されず，不溶性沈殿物と結びついて運 ばれるか，あるいは粘土鉱物の表面に吸着している。
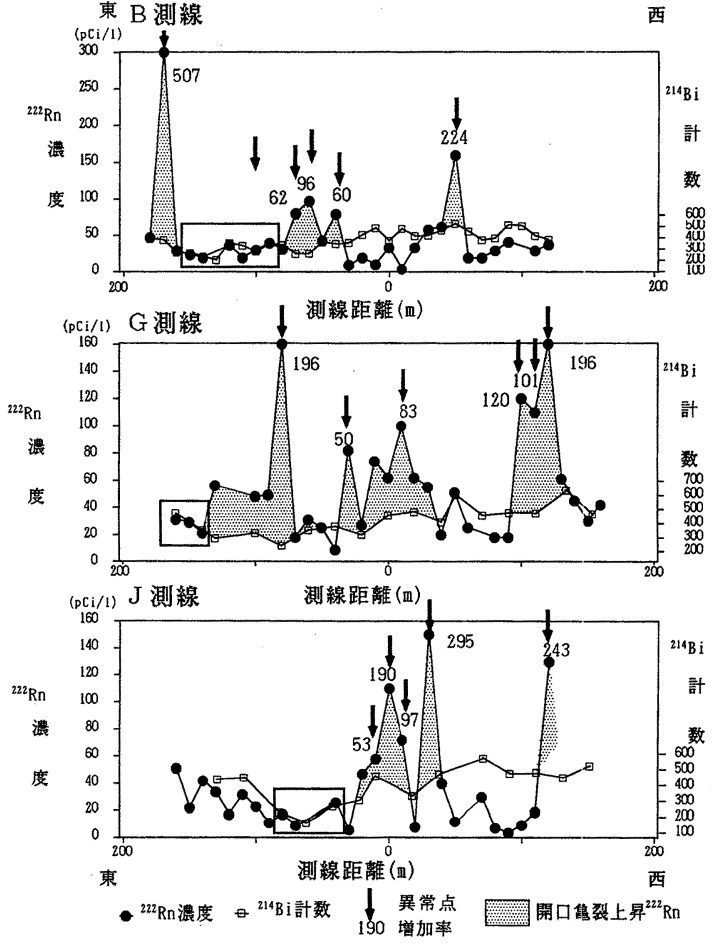

図-14 土中 ${ }^{222} \mathrm{Rn}$ 濃度の変化

表 -3 土中 ${ }^{222} \mathrm{Rn}$ 濃度の測定結果

\begin{tabular}{|c|c|c|c|c|c|c|c|}
\hline \multirow{2}{*}{\multicolumn{2}{|c|}{ 距離(m) }} & \multicolumn{2}{|c|}{ B測線 } & \multicolumn{2}{|c|}{ G測線 } & \multicolumn{2}{|c|}{ J測線 } \\
\hline & & $(\mathrm{pCi} / \mathrm{l})$ & 諆差\% & $(\mathrm{pCi} / \mathrm{l})$ & 諆差\% & $(\mathrm{pCi} / \mathrm{l})$ & 俱差\% \\
\hline 東 & 180 & 47.0 & 8.1 & & & & \\
\hline & 170 & $\begin{array}{r}300.0 \\
0\end{array}$ & 9.8 & & & & \\
\hline & $\begin{array}{l}160 \\
150\end{array}$ & 29.0 & $\begin{array}{r}9.9 \\
10.0\end{array}$ & $\begin{array}{l}11.0 \\
29.0\end{array}$ & $\begin{array}{r}9.9 \\
10.0\end{array}$ & $\begin{array}{l}1.0 \\
22.0\end{array}$ & $\begin{array}{l}9.9 \\
9.9\end{array}$ \\
\hline & 140 & 19.0 & 10.0 & 21.0 & 10.0 & 42.0 & 10.0 \\
\hline & 130 & & & 56.0 & 10.0 & 34.0 & 10.0 \\
\hline & 120 & 36.0 & 9.9 & & & 17.0 & 8.4 \\
\hline & 110 & 19.0 & 10.0 & & & 32.0 & 6.2 \\
\hline & 100 & 30.0 & 8.8 & 48.0 & 10.0 & 23.0 & 9.9 \\
\hline & 90 & 39.0 & 10.0 & 49.0 & 8.9 & 11.0 & 10.0 \\
\hline & 80 & 31.0 & 9.8 & 160.0 & 9.8 & 17.0 & 9.9 \\
\hline & 70 & 80.0 & 9.9 & 18.0 & 9.2 & 9.0 & 9.9 \\
\hline & 60 & 97.0 & 9.8 & 31.0 & 7.1 & & \\
\hline & 50 & 43.0 & 9.9 & 25.0 & 7.0 & & \\
\hline & 40 & 79.0 & 9.3 & 8.5 & 10.0 & 26.0 & 9.9 \\
\hline & 30 & 9.4 & 10.0 & 82.0 & 9.7 & 5.9 & 10.0 \\
\hline & 20 & 19.0 & 10.0 & 27.0 & 10.0 & 47.0 & 9.1 \\
\hline & 10 & 10.0 & 10.0 & 74.0 & 10.0 & 58.0 & 9.9 \\
\hline & 0 & 33.0 & 10.0 & 62.0 & 9.9 & 110.0 & 9.9 \\
\hline & 10 & 3.4 & 11.7 & 100.0 & 9.9 & 72.0 & 9.8 \\
\hline & 20 & 33.0 & 7.0 & 62.0 & 9.9 & 7.9 & 10.0 \\
\hline & 30 & 58.0 & 9.9 & 55.0 & 8.4 & 150.0 & 9.8 \\
\hline & 40 & 62.0 & 10.0 & 20.0 & 8.8 & 40.0 & 9.9 \\
\hline & 50 & 160.0 & 10.0 & 51.0 & 9.9 & 12.0 & 10.0 \\
\hline & 60 & 19.0 & 10.0 & 25.0 & 9.9 & & \\
\hline & 70 & 19.0 & 10.0 & & & 30.0 & 8.8 \\
\hline & 80 & 29.0 & 10.0 & 18.0 & 10.0 & 7.3 & 10.0 \\
\hline & 90 & 41.0 & 9.8 & 18.0 & 9.2 & 3.7 & 11.3 \\
\hline & 100 & & & 120.0 & 10.0 & 9.5 & 10.0 \\
\hline & 110 & 29.0 & 10.0 & 110.0 & 10.0 & 19.0 & 10.0 \\
\hline & 120 & 37.0 & 9.2 & 160.0 & 10.0 & 130.0 & 9.6 \\
\hline & 130 & & & 61.0 & 9.9 & & \\
\hline & 140 & & & 45.0 & 9.9 & & \\
\hline & 150 & & & 30.0 & 10.0 & & \\
\hline 西 & 160 & & & 42.0 & 10.0 & & \\
\hline
\end{tabular}




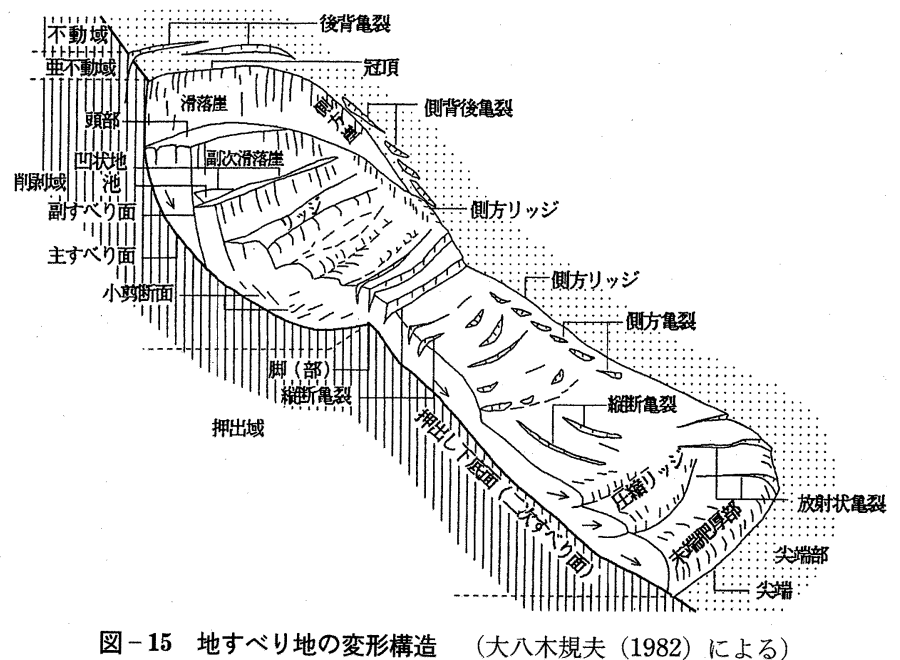

堆積岩中のウラン鉱床には，地下水型と呼ばれる陸成 の砂岩, 踏岩に伴われるウラン鉱床がある20)。このウ ラン鉱床は砂岩, 磁岩の堆積後に, 地下水の流れの停滞 する還元的な環境で地下水中から U が沈殿することに より形成したものと考えられている20)。地下水型ウラ ン鉱㦿の特徵は, Th をほとんぞ伴わないことである。 同じように風化帯を浸透した地下水に溶解したUが, 還元環境に移動すれば，Uのみが沈殿・濃集すること が推定される。この場合, ${ }^{214} \mathrm{Bi} /{ }^{208} \mathrm{~T} 1$ の異常が生じるで あろう。今泉他 ${ }^{16)}$ は還元環境の場として断層粘土によ り地下水が堰止められ，停滞している環境を考えた。今 回の調査の ${ }^{214} \mathrm{Bi} /{ }^{208} \mathrm{Tl}$ の異常も断層粘土による地下水の 停滞場で生じているものと考えられる。この考えが正し いなら， ${ }^{214} \mathrm{Bi} / 208 \mathrm{~T} 1$ の異常点の連続性から図ー13に示す 断層が推定できる。

実線で示した断層は, 大池左岸付近から NNE 方向に 延びる断層（西断層と言う）と大池地すべり中央部を切 る断層（中央断層々言う）で, 異常点が 7 点 10点連 続しており確実度の高い断層である。西断層と中央断層 は, 図-7で推定した 2 断層に対応するものと考えられ る。図-8の断層谷は中央断層によって形成されたもの であろう。大池地すべりの東側に NNE 方向の断層と西 断層, 中央断層の間に $\mathrm{NE}$ 方向の断層も推定される。 これらの断層は異常点が 5 点連続するものであるが, 放射能探査以外の情報がないので確実度の劣るものとし て示した。推定された NNE 方向の断層系は, 調查地域 周辺の福曲構造, 断層系々調和的であり7), これまで報 告されていないが大規模な断層であると考えられる。

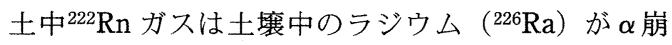

壞し，反跳ににより粒子から間隙に放出されたものであ る。土中 ${ }^{22} \mathrm{Rn}$ ガスの濃度異常は, 土壤粒子中の $\mathrm{U}$ ${ }^{2}{ }^{226 \mathrm{Ra})}$ の濃度, 分布に依存する。また, ${ }^{222} \mathrm{Rn}$ の反跳範 囲は, $0.05 \mu \mathrm{m}$ 以下であるので22), 同じUの濃度, 分 布であっても, 土壌粒子の表面積の大きい方が ${ }^{222} \mathrm{Rn}$ 濃 度は高くなることが期待される ${ }^{23)}$ 。ひとたび， ${ }^{22} 2 \mathrm{Rn}$ が 土壌粒子から間隙に放出されると, ${ }^{222} \mathrm{Rn}$ の移動, 濃縮 は, 地層の透水性, 割れ目の性格, 風化の違い, 含水比 に影響される ${ }^{23)} 。$

${ }^{222} \mathrm{Rn}$ ガスは, ウラン系列核種での唯一の気体である ので, 地すべり運動により泥岩中に地下から地表まで連 続する亀裂が生じた部分は, ${ }^{22} \mathrm{Rn}$ ガスの通風管として の役割を果たし，地上付近で濃度異常を形成する。

亀裂での ${ }^{222} \mathrm{Rn}$ の移動メカニズムには拡散によるもの と, 非拡散の移流により間隙の流体（地下水, 二酸化炭 素などの気体等）が移動するのに伴い一緒に運ばれるも のとがある。開口性の亀裂を上昇する ${ }^{222} \mathrm{Rn}$ の主要移動 メカニズムは移流である ${ }^{24)}$

今回測定された ${ }^{22} \mathrm{Rn}$ 濃度の変動には, 土壌・基盤中 に含をれるUの崩壊核種として拡散により地表に運ば れた ${ }^{222} \mathrm{Rn}$ と, 亀裂を上昇してきた非拡散の ${ }^{222} \mathrm{Rn}$ の情

\footnotetext{
* 反跳 : 弾丸を発射した砲は, 運動量保存の法則によって, 跳ね返される。同じように $\alpha$ 粒子を放射した娘核種なども， 跳ね返される。この現象を反跳と言う。土粒子表面の ${ }^{226} \mathrm{Ra}$ $\rightarrow{ }^{222} \mathrm{Rn}$ の崩壊では, $\alpha$ 粒子が放出され, 放出したエネルギ 一に応じて ${ }^{222} \mathrm{Rn}$ に運動エネルギーが与えられ, 粒子外に飛 び出る。粒子内部の ${ }^{222} \mathrm{Rn}$ は与えられる運動エネルギーが 粒子外に出るためのエネルギーより小さいために, 粒子内 部に封じ込められる。
} 


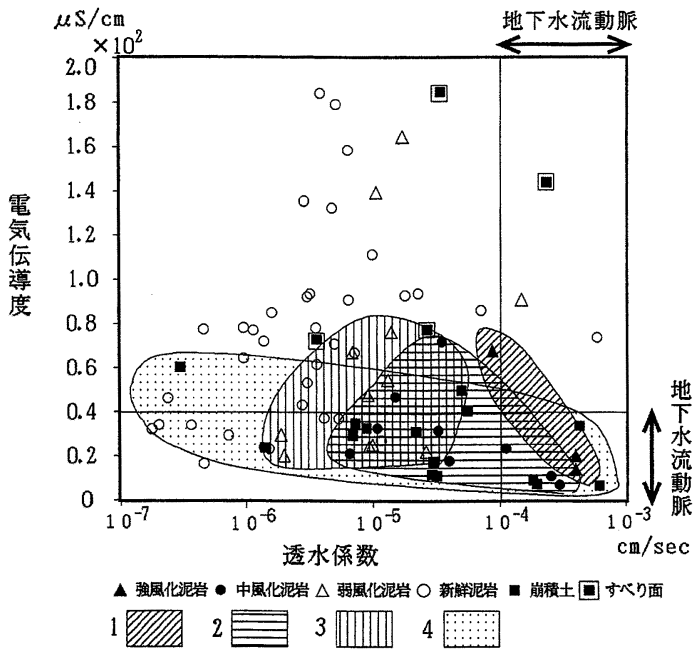

図-16 土層区分毎の電気伝導度と透水係数の関係 $1:$ 強風化泥岩の範囲 $2:$ 中風化泥岩の範囲 $3:$ 弱風化泥岩の範囲 $4:$ 崩積土の範囲

報が含まれている。 $\mathrm{B}, \mathrm{G}, \mathrm{J}$ 測線の ${ }^{222} \mathrm{Rn}$ 濃度変化から， 土壤・基盤の ${ }^{222} \mathrm{Rn}$ 濃度成分（これをバックグラウンド と呼ぶ）を除去できれば，開口亀裂を上昇してきた ${ }^{222} \mathrm{Rn}$ 量を推定できる。ここでは, ${ }^{214} \mathrm{Bi}$ の測定值を土壌 ·基盤の ${ }^{238} \mathrm{U}$ 量とし，この変化パターンは土壤と基盤 からの ${ }^{222} \mathrm{Rn}$ 濃度変化パターンと相似であると仮定し て, ${ }^{214} \mathrm{Bi}$ の変化を ${ }^{222} \mathrm{Rn}$ 濃度のバックグラウンドに変換 した ${ }^{15)}$ 。

図-14に示す各測線の ${ }^{222} \mathrm{Rn}$ 濃度変化と ${ }^{214} \mathrm{Bi}$ 計数変 化のうち, 四角で囲んだ部分の ${ }^{222} \mathrm{Rn}$ ガス濃度変化をす べて土壤中の $\left.{ }^{238} \mathrm{U}{ }^{214} \mathrm{Bi}\right)$ に由来するものとする。そこ で, 四角で囲んだ測定点の ${ }^{214} \mathrm{Bi}$ の変化と ${ }^{222} \mathrm{Rn}$ 濃度変化 が一致するように ${ }^{214} \mathrm{Bi}$ 変化曲線を拡大縮小し，この変 形した ${ }^{214} \mathrm{Bi}$ 変化パターンを ${ }^{222} \mathrm{Rn}$ 濃度のバックグラウン ド変化とした。開口性の亀裂を通って地表まで上昇して きた ${ }^{222} \mathrm{Rn}$ 量は, この拡大された ${ }^{214} \mathrm{Bi}$ の変化パターンを 超える ${ }^{222} \mathrm{Rn}$ 量と推定される（図-14）。各測線の ${ }^{222} \mathrm{Rn}$ 濃度変化曲線のうちハッチで示した部分は, 開口性の亀 裂を通じて地上に到達した ${ }^{222} \mathrm{Rn}$ 量を示しており, 異常 点はこの ${ }^{222} \mathrm{Rn}$ 量により形成されている。 ${ }^{222} \mathrm{Rn}$ の異常 点分布は, 小地すべり地形の上部の滑落崖, 側方の滑落 崖, 末端隆起部の亀裂（図-15)付近に分布して抢り（図 -13), 開口性の亀裂は地すべり運動によるものと考え られる。

\section{2 浅層地下水流動脈}

（1）浅層地下水流動脈の形成場

図-16には土層区分毎の EC と透水係数の関係を示し

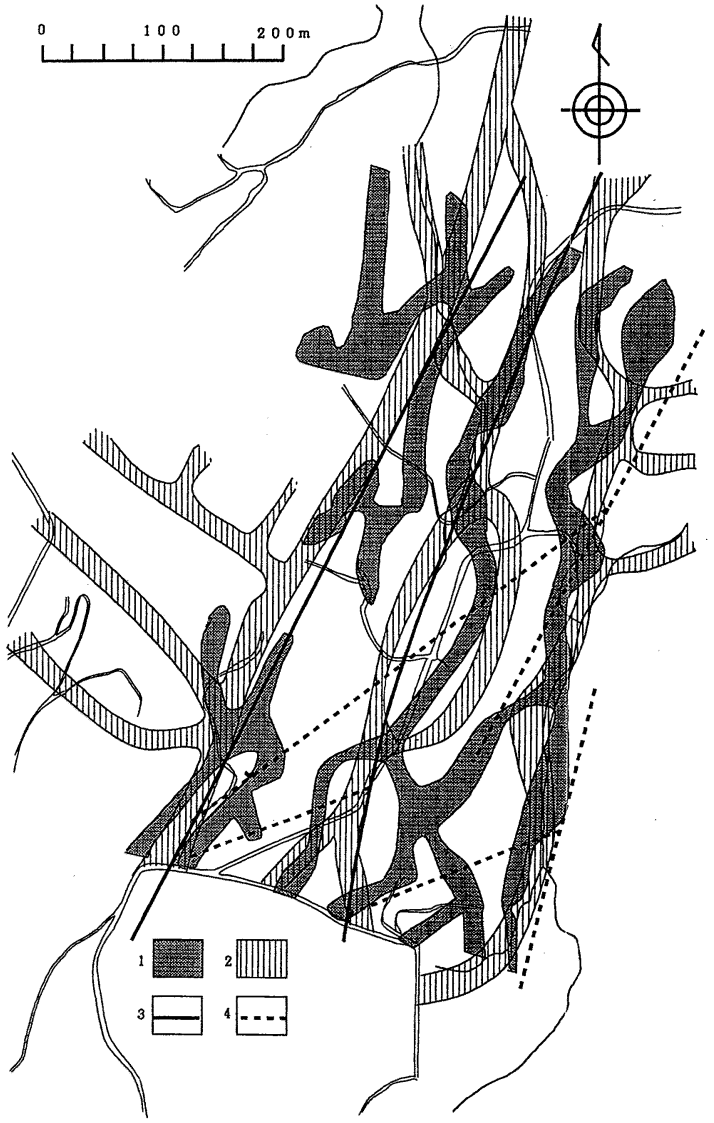

図-17 浅層地下水流動脈と断層, 小地すべり地形との関 係

$1: 1 \mathrm{~m}$ 深地温探査の地下水流動脈

2：小地すべり地形から推定した亀裂帯

$3:$ 確実度の高い断層 $4:$ 確実度の劣る断層

た。タイプ1の土層区分では, 強風化泥岩, 中風化泥 岩, 弱風化泥岩と風化の程度が弱くなるに従い, 透水係 数が $10^{-3} \mathrm{~cm} / \mathrm{s} \sim 10^{-5} \mathrm{~cm} / \mathrm{s}$ まで低下し， ECが大きく なっている。透水係数が $10^{-5} \mathrm{~cm} / \mathrm{s}$ 以下では， $\mathrm{EC} は$ $800 \mu \mathrm{S} / \mathrm{cm}$ 以下で増加しなくなる。一方, 新鮮泥岩（弱 風化泥岩の一部) は透水係数と EC の間に明瞭な関係は ない。これは, 新鮮泥岩中の地下水の水質が可溶性塩類 の溶解のほかに, モンモリロナイトの形成, 方解石の沈 澱, $\mathrm{Ca}^{2+}-\mathrm{Na}^{+}$イオン交換等の水質形成因子が加わる ためである (今泉, 準備中)。崩積土層では, 強風化泥 岩, 中風化泥岩, 弱風化泥岩と新鮮岩の一部の分布域を 包含する範囲に分布するものと地すべり面と関係した地 下水とがある。

地すべり地の地下水追跡調查結果を総合すると, 透水 係数の大きいものが $10^{-2} \sim 10^{\circ} \mathrm{cm} / \mathrm{s}$ であり，一般的に 
は $10^{-3} \mathrm{~cm} / \mathrm{s}$ である。前者の透水係数の数值は, 均一土 層の透水の流速としては過大であり, 亀裂を流動する地 下水流動脈の流速と考えざるをえない3),17)。10-3 cm/s が地下水追跡調査での地下水流動脈の透水係数を示して いるものと考えられる。簡易揚水試験による透水係数は $3 \mathrm{~m}$ 区間の平均值であるので, 地下水追跡調查の透水係 数より低めの透水係数を示すことが推定される。したが って, 図-16の $10^{-4} \sim 10^{-3} \mathrm{~cm} / \mathrm{s}$ (崩積土の頻度分布の うち高透水性の山の範囲) は地下水流動脈の透水係数を 示していると考えられる。崩積土からすべり面と関係し た高 $\mathrm{EC}$ の地下水を除外すると, 崩積土中にある地下水 流動脈の地下水の $\mathrm{EC}$ は $400 \mu \mathrm{S} / \mathrm{cm}$ 以下を示す。透水 係数 $10^{-4} \sim 10^{-3} \mathrm{~cm} / \mathrm{s}, \mathrm{EC} 400 \mu \mathrm{S} / \mathrm{cm}$ 以下には強風化 泥岩, 中風化泥岩中の一部もプロットされる。これらの 土層中にも地下水流動脈は形成されているものと考えら れる。

(2)浅層地下水流動脈の成因

第三紀層地すべり斜面の地下水流動を規制する地質構 造には，地すべり運動によるものと，そうでないものと がある。ここでは後者を, 地質構造規制と呼び, 前者を 地すべり運動規制と呼ぶ。

地質構造規制は, 断層, 褶曲等の地質構造や, 岩, 土 自身の物理性・力学性・風化特性等に基づくと思われる 亀裂や土中の空隙である。地すべり活動規制は地すべり の運動により作られた亀裂網である。

ここでは, $1 \mathrm{~m}$ 深地温探査の地下水流動脈と $\gamma$ 線スペ クトロメトリーから推定された断層系, 小地すべり地形 の滑落崖, 側方崖の連続から推定した亀裂帯との関係を 考察する。

(1)地質構造規制

図-17に $1 \mathrm{~m}$ 深地温探査の浅層地下水流動脈之断層 の関係を示した。西地下水流動脈は西断層と調和的に分 布している。中央地下水流動脈は斜面下部では中央断層 と一致している。東地下水流動脈と断層の関係はない。

${ }^{214} \mathrm{Bi} /{ }^{208} \mathrm{~T} 1$ の異常が断層粘土による地下水の停滞場を 示しているとすると, 断層線自体は地下水流動脈にはな りえず，むしろ地下水のバリアとしての役割を果たして いるものと考えられる。本地域の小断層群は, 断層面の 性質・切断関係から，大きく新旧 2 系統が識別されて おり ${ }^{7)}$, 新期小断層系はNNE方向に発達し, 開離 (open) 接触（touched）型を示す。主断層の付近には 断層運動により形成された小断層が発達しているものと 考えられる。花崗岩地域の放射能探査では, 断層粘土の 外側に開口亀裂部があることが示されている15)。断層 谷中の B3 の崩積土層中では最も大きな透水係数が得ら
れており, 地下水は主断層からややずれて, これと平行 するように発達した小断層系を流動しているものと考え られる。西地下水流動脈の全体, 中央地下水流動脈の斜 面下部は, 断層亀裂の連続性により形成されてたものと 考えられる。

\section{(2)地すべり運動規制}

地すべり土層の透水性は一般に低いが, 表層部地すべ り土層, 基盤上部の風化帯あるいは上記の各層準の地す ベり土層群の境界部ではやや高い值を示すので19), 小 地すべりの境界が地下水流動脈を形成している可能性が ある。

図-17には, 地下水流動脈分布, 小地すべり地形の 滑落崖の連続性から推定した亀裂帯の関係も示されてい る。西地下水流動脈は小地すべり地形から推定した亀裂 帯とは一致せず, 亀裂帯の東側を平行している。中央, 東地下水流動脈は亀裂帯とほほ一致している。中央地下 水流動脈は斜面下部では断層とも関係しているが, 主要 な成因は小地すべり地形の亀裂帯を流動しているものと 考えられる。東地下水流動脈も亀裂帯を流動し, 斜面上 部では渓流水の伏流したものから形成されている。

\section{6. ま め}

浅層地下水流動脈は, 周辺より透水性の大きい部分が ある範囲に連続性を有して広がっている部分である3)。 浅層地下水流動脈の地下水には, 降雨を供給源とするも のと, 深層地下水を供給源とするものがある。降雨を供 給源とするものは, 大規模地すべり内の局部的な変動に 大きく関与する。深層地下水を供給源とするものは, わ ずかな水位変動でも深層地下水に影響を及ぼし, 大規模 な地すべり活動を誘発する可能性があるので4), 地すべ り対策工の検討では, 地下水流動脈の分布・成因を調査 することは重要である。

新潟県板倉町の大池周辺の大規模な大池地すべり地で は, $1 \mathrm{~m}$ 深地温探查実施したところ, 大池左岸から流出 する西地下水流動脈, 大池提体中央部加流出する中央 地下水流動脈, 大池の東側の沢沿いを流下する東地下水 流動脈が存在することが明らかになった。

内藤他 ${ }^{4)}$, 内藤・田中5) $\left({ }^{5}\right.$ 六甲山系の地すべり地の地 下水が, 浅層地下水, 浅層地下水流動脈地下水, 中間地 下水, 深層地下水の 4 つに区分されることを示し, 地 下水流動脈は崩積土層中に形成されることを報告してい る。今回の調查結果では, 崩積土層中以外に, 強風化泥 岩, 中風化泥岩にも地下水流動脈が形成されていること が明らかになった。

$1 \mathrm{~m}$ 深地温探査の地下水流動脈と $\gamma$ 線スペクトロメト 
リーから推定され断層系，小地すべり地形の滑落崖，側 方崖の連続から推定した亀裂帯との関係を検討した結 果, 次のことが明らかになった。西地下水流動脈は断層 亀裂の連続性により形成されており，中央地下水流動脈 は斜面下部では断層とも関係しているが，主要な成因は 小地すべり地形の亀裂帯を流動しているものと考えられ る。東地下水流動脈も亀裂帯を流動し, 斜面上部では渓 流水の伏流したものから形成されている。

地下水流動脈の調査方法としては, $1 \mathrm{~m}$ 深地温探查と 地すべり地形調查によりその分布を概定する事は可能で ある。しかし，地下水流動脈の成因，特に断層・龟裂と 地下水流動脈の関係を明確にするためには放射能探査を 併用する必要がある。集水井や水挍きボーリング等の地 下水低下対策工の適切な配置計画には, 地下水流動脈の 総合的な資料が不可欠である。

\section{参 考 文 献}

1）稲葉一成·吉田昭治・佐藤修 - 中野俊郎 (1991) : 孔内水 位の連続観測と水質調查を併用した地すべり斜面の地下水 解析一東虫龟地区を例として一，地すべり，Vol. 28, No. 3 , pp. $17-24$.

2）竹内篤雄 (1972)：地すべり地に打ける地下水調査法につ いて一新しい地下水調查法の必要性とその試久一，地す ベり, Vol. 8, No. 3, pp. 3-12.

3）竹内篤雄 (1983)：地すべり地温測定による地下水調査 法, 吉井書店, $196 \mathrm{p}$.

4）内藤光雄・竹内篤雄・田中茂（1983）: 六甲山系地すべり 地に打ける層別地下水の挙動について. 日本地下水学会誌, Vol. 25, No. 1, pp. $1-16$.

5）内藤光男・田中茂 (1984) : 神戸層群に属する一地すべり 地に打ける層別地下水の分類方法ならびにその挙動につい て, 日本地下水学会, Vol. 26, No. 4, pp. 167-183.

6）栃木省二・大内章義（1986）: 自然放射能探査と電気探 查, 地すべり, Vol. 23, No. 2, pp. 34-38.

7) 中村和善 (1982): 新潟県高田平野南方地域における後期 新生代の構造運動一その 1 堆積盆の変遷と基盤の運動像 一, 地質学雑誌, Vol. 88, No. 3, pp. 155-175.
8）北陸農政局（1993）: 平成 4 年度北陸農政局板倉農地保全 事業大池周辺水理地質調査業務報告書, 北陸農政局.

9）古谷尊彦 (1980)：地すべりと地形，地すべり・崩壊・土石 流一予測と対策, 鹿島出版, pp. 192-230.

10）青木滋・中村三郎 (1983)：土砂災害の予知と対策 - 3 地すべり一，土と基礎，Vol. 31, No. 4, pp. 71-78.

11）北陸農政局 (1994): 平成 5 年度北陸農政局板倉農地保全 事業大池周辺水理地質調査業務（その2）報告書，北陸農 政局.

12）奥山武彦 (1989)：浅部地温測地による地下水流脈調査 農土誌, Vol. 57 , No. 4, pp. 11-16.

13）奥山武彦・今泉眞之 (1994) : 疎な測点配置の地温探査に よって地下水流動脈の位置を推定する方法, 農土論集, No. 173 , pp. $49-57$.

14）今泉缜之・小前隆美・浜田浩正 (1992) : $\gamma$ 線スペクトロ メトリーによる断層調查一長野県山口村の阿寺断層を例 として一, 応用地質, Vol. 33, No. 2, pp. 31-43.

15）今泉眞之 ·竹内睦雄・小前隆美（1993）：長野県山口村の 阿寺断層の土堙ガス中のラドン濃度と $\gamma$ 線スペクトロメト リーの違いについて, 応用地質, Vol. 34, No. 1, pp. 1 13.

16）大八木規夫 (1982)：地すべりの構造, アーバンクボタ, No. 20 , pp. $42-46$.

17）岸本良次郎 (1972)：地すべり地の地下の水の動態（I）, 日本地下水学会誌, Vol. 14, No. 1, pp. 1-8.

18）玉田文吾 (1985): 地すべり面の種類と力学的性質との関 係. 地すべり, Vol. 22, No. 2, pp. 14-21.

19）新篫静夫・田中芳則 (1982)：地すべり土層の水文地質学 的検討と融雪水の動態 (I), 地すべり, Vol. 18, No. 3, pp. $54-62$.

20）片山信夫 (1961) : 堆積岩中のウラン鉱床の成因, ウラン - その資源之鉱物，朝倉書店，pp. 161-171.

21）橋本哲夫（1994）：自然界での放射壊変系列の非平行生起 の原因について, RADIOISOTOPES, No. 43, pp. 212 223.

22) Krishnaswami, S. and Seidemann D. E. (1988): Comparative study of ${ }^{222} \mathrm{Rn},{ }^{40} \mathrm{Ar},{ }^{39} \mathrm{Ar}$ and ${ }^{37} \mathrm{Ar}$ leakage from rocks and minerals: Implications for the rock of nanosecond in gas transport through natural silicates, Geochim. Cosmochim. Acta, Vol. 52, pp. 655 - 658 .

23) Ball T. K., Cameron D. G., Colman T. B. and Roberts P. D. (1991): Behaviour of radon in the geological environment: a review, Quarterly Journal of Engineering Geology, vol. 24 , pp. $169-182$.

24) TANNER, A. B. (1980): Radon migration in the ground: A supplementary review, Natural Radiation Environment III, Symposium Proceedings, US DOE, NTIS Report CONF-780422, Vol. 1, pp. 5-56.

(1995年 5 月 1 日受付, 1995 年 7 月 26 日受理) 